\title{
Girls' adolescence in Burkina Faso: A pivot point for social change
}

Martha Brady

Population Council

Lydia Saloucou

Erica Chong

Follow this and additional works at: https://knowledgecommons.popcouncil.org/departments_sbsr-pgy

Part of the Demography, Population, and Ecology Commons, Family, Life Course, and Society Commons, Gender and Sexuality Commons, Gender Equity in Education Commons, International Public Health Commons, and the Maternal and Child Health Commons How does access to this work benefit you? Let us know!

\section{Recommended Citation}

Brady, Martha, Lydia Saloucou, and Erica Chong. 2007. "Girls' adolescence in Burkina Faso: A pivot point for social change." New York: Population Council. 


\section{GIRLS'ADOLESCENCE IN BURKINA FASO}

\section{A pivot point for social change}

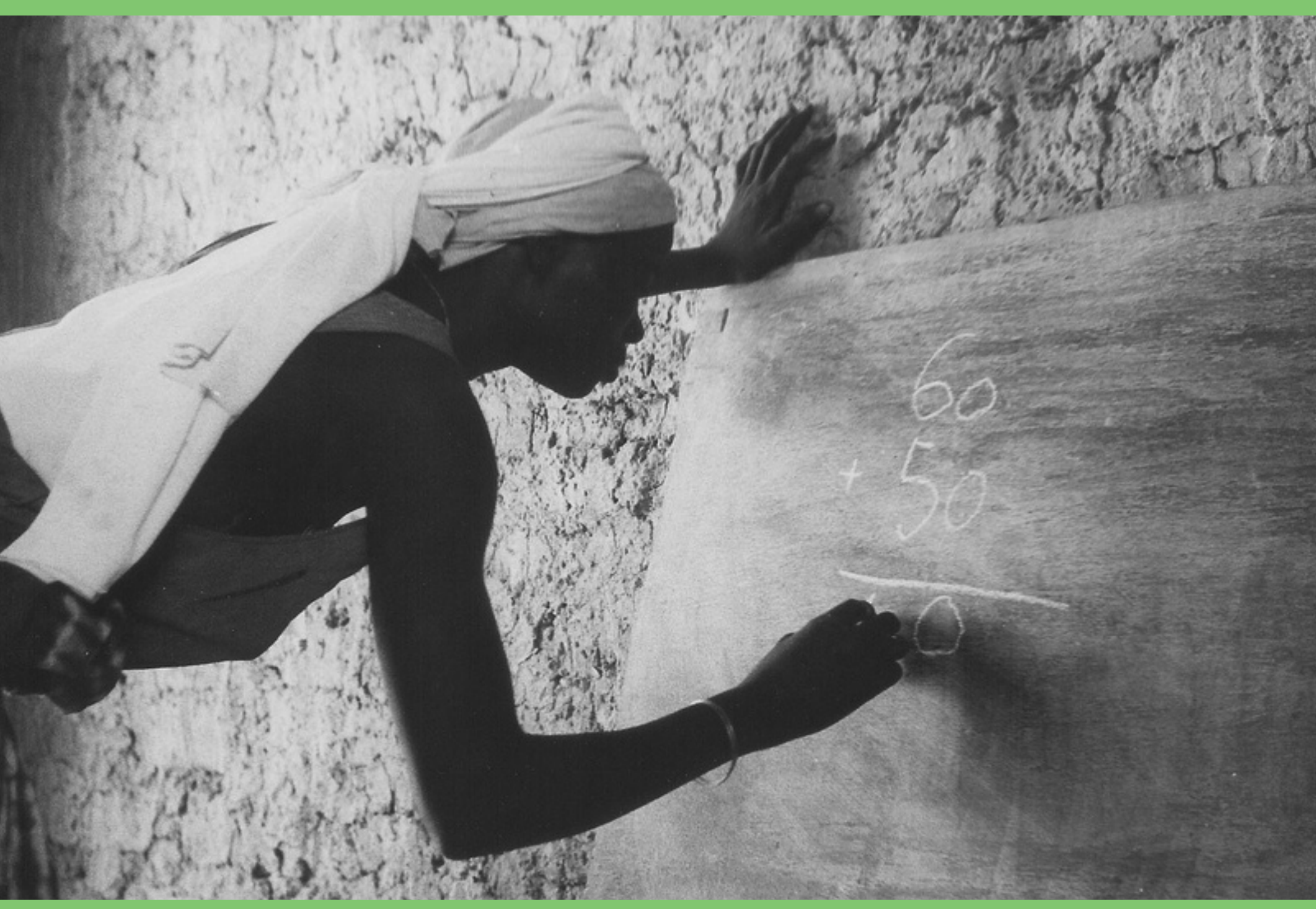

MARTHA BRADY

LYDIA SALOUCOU

ERICA CHONG

(P) Population Council 


\section{GIRLS'ADOLESCENCE IN BURKINA FASO}

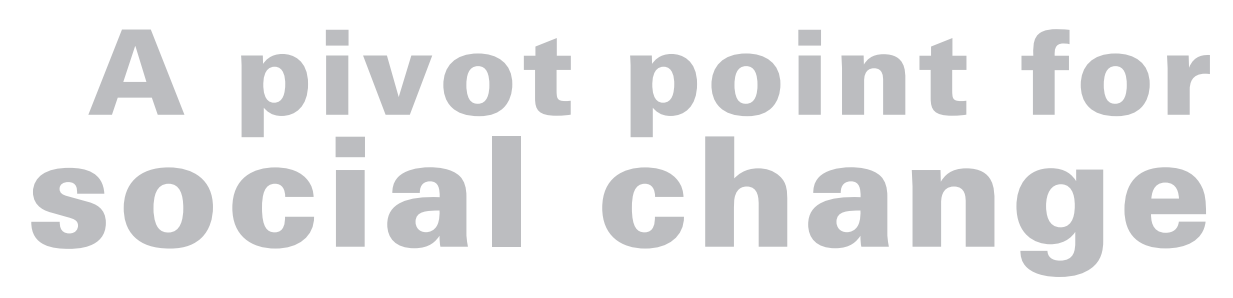

MARTHA BRADY LYDIA SALOUCOU ERICA CHONG 


\section{(2) Population Council}

The Population Council conducts research worldwide to improve policies, programs, and products in three areas: HIV and AIDS; poverty, gender, and youth; and reproductive health.

(C) 2007 The Population Council, Inc.

Population Council

36, Avenue de la Liberté

01 B.P. 6250

Ouagadougou, BURKINA FASO

Tel: +22650 3112 42/3

Fax: +22650311246

Population Council

One Dag Hammarskjold Plaza

New York, NY 10017 USA

Tel: +1 2123390500

Fax: +1 2127556052

http://www.popcouncil.org

Cover photo by Brenda Gael McSweeney.

Design by Mike Vosika. 


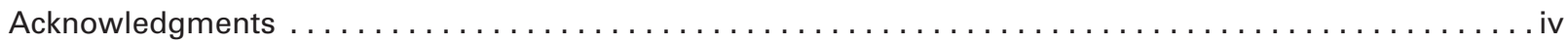

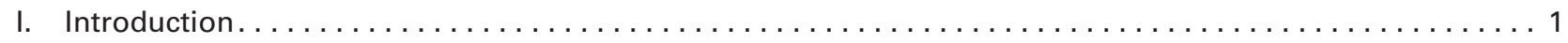

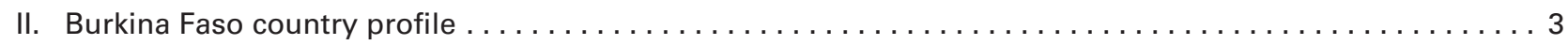

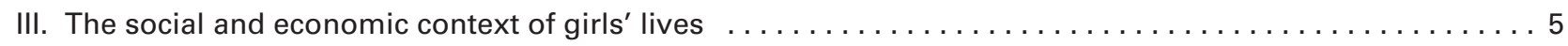

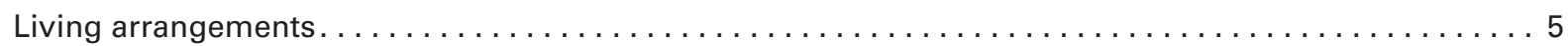

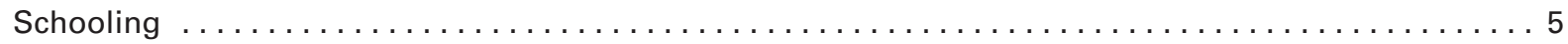

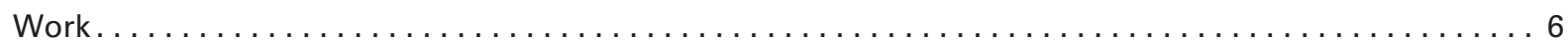

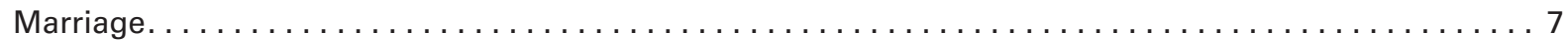

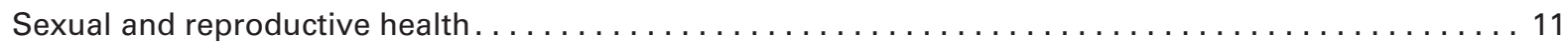

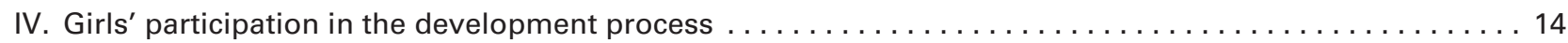

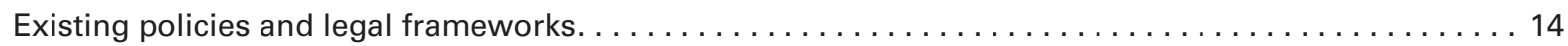

Girls' participation in conventional youth-serving initiatives $\ldots \ldots \ldots \ldots \ldots$

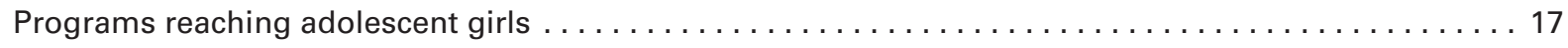

V. Adolescent girls in Burkina Faso: A forward-looking agenda $\ldots \ldots \ldots \ldots \ldots$

Infants and young children: A healthy, documented beginning to girls' lives . . . . . . . . . . 24

Schooling: Helping girls arrive at school on time and keeping them there. $\ldots \ldots \ldots$

Support, protection, and legal redress for girls in extreme circumstances . . . . . . . . . . .

Creating a socially supportive environment for girls in rural areas $\ldots \ldots \ldots \ldots$

Delaying marriage until 18, making the transition to marriage safer, and supporting married girls . . . . 28

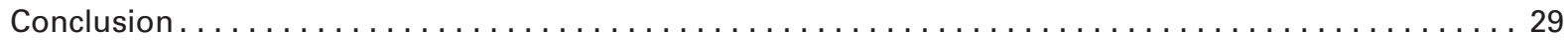

VI. Appendix: Activity register for youth-serving organizations $\ldots \ldots \ldots \ldots \ldots \ldots$

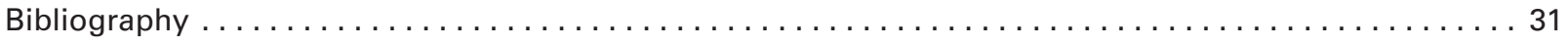


T he Population Council's Gender, Family, and Development (GFD) program has been actively involved in adolescent program and policy work in Burkina Faso for a number of years. We have learned a great deal about challenges and opportunities faced by young people, in particular, Burkinabé girls. This report is intended to give a broad overview of girls' adolescencethe realities of their lives and the policy and program initiatives designed for them. The authors' goal was to be as inclusive and comprehensive as possible, although we recognize that omission of initiatives is inevitable. We have drawn from a number of data sources including Population Council studies and programs and the Burkina Faso Demographic and Health Survey 2003 (EDSBF-III). In addition, we have attempted to summarize policy and program information provided by several organizations.

The authors thank the following donors for their support for this project: the Bill \& Melinda Gates Foun- dation, the Department for International Development (UK) (DFID), the United Nations Foundation, and the United Nations Population Fund (UNFPA). We would like to thank our Population Council friends and colleagues: Judith Bruce for her intellectual guidance of this project, Annabel Erulkar, Placide Tapsoba, Carey Meyers, and Heidi Jones for their review and input, and Michelle Skaer for her research assistance. We acknowledge the valuable insights and comments of our reviewers, Ann Biddlecom and Jennifer Blum. We also thank Christine Heritier for her translation.

Finally, we are grateful to the following researchers who participated in the Population Council studies and who have contributed to policy and program discussions in Burkina Faso: Cyrille Compaoré, Mahamadi Cissé Mamadou Djibril Mar, Ida Nikyema-Tamini, Gisèle Kaboré, Kotolama Traoré, Zakari Congo, Youssouf Langani, and Natalie Sawadogo. 


\section{INTRODUCTION}

$\square$ xperiences in adolescence powerfully affect boys' and girls' adult lives, suggesting that interventions during the second decade of life have the potential to improve greatly their health and their social and economic status. During this time, boys and girls experience biological, social, and psychological changes related to puberty and often undergo major transitions in their lives. These may include initiation of sexual relations, marriage, childbearing, and increased household and familial responsibilities. As a result, adolescents increasingly have been the focus of policy and programmatic efforts during the past decade; initiatives having been directed at improving school enrollment and quality, making health services more "youthfriendly," educating young people about reproductive health, and more recently, addressing their economic concerns. Clearly investments in adolescents are vital for:

- implementing the United Nations Convention on the Rights of the Child;

- defending girls' rights to later, informed, and voluntary marriage;

- protecting their reproductive health and helping them to establish positive health habits;

- realizing investments in human capital, including health investments made in early childhood;

- reducing gender disparities in terms of health and social, and economic resources;

- building an effective economic base for teenagers, especially in poorer areas, where many are ill prepared to begin their economic lives; and

- increasing the span between generations and reducing rapid population growth (Bruce and Chong 2006).

As closer attention is paid to the lives of adolescents in sub-Saharan Africa, girls are found to be clearly disadvantaged, compared with their male counterparts. Girls' lives are frequently confined to rigid domestic roles and responsibilities; they experience restricted mobility and interaction with the wider community, inadequate schooling, insufficient opportunities to work for pay, early marriages arranged without their consent, early childbearing soon after marriage, and limited control over their reproductive health and fertility.

$$
\begin{aligned}
& \text { Understanding and recognizing girls' } \\
& \text { realities is an important first step in } \\
& \text { planning appropriate and meaningful } \\
& \text { interventions for them. Laying this } \\
& \text { foundation is especially critical in } \\
& \text { Burkina Faso, where girls' experiences } \\
& \text { are remarkably diverse. }
\end{aligned}
$$

This characterization of girls' lives is particularly true for adolescent girls in Burkina Faso. Nearly three out of four girls aged 15-19 have not completed four years of schooling, and 74 percent cannot read (INSD and ORC Macro 2004). Burkinabé girls face restrictions to their movements in the community, to their access to resources such as land, and to their employment in the formal sector. Marriage frequently occurs early, and more than one-third of married girls find themselves in polygamous unions as second or third wives, married to much older men. Once married, girls are expected to bear children early. Girls in Burkina Faso typically give birth within the first 20 months of marriage, and a girl who fails to bear children immediately after marriage risks rejection by her husband or his family. The low status of girls and women makes them especially vulnerable in the context of the HIV epidemic, although current 
national HIV rates remain relatively low. An estimated 1.4 percent of girls are infected with HIV, compared with 0.5 percent of boys (UNAIDS 2006). ${ }^{1}$

Understanding and recognizing girls' realities is an important first step in planning appropriate and meaningful interventions for them. Laying this foundation is especially critical in Burkina Faso, where girls' experiences are remarkably diverse. The lives and capacities of Burkinabé girls are not only affected by age, ethnicity, schooling status, urban-rural residence, and parental residence, but also by their status vis-à-vis marriage. Girls who are unmarried, "promised," 2 engaged, or married face different constraints, have differing needs, and merit specific program approaches.
This report aims to fill gaps in our knowledge regarding adolescent Burkinabé girls so as better serve the needs of this most vulnerable population. Section II presents a basic profile of Burkina Faso, providing the social, economic, and cultural context in which adolescent girls live. Section III examines the existing data concerning the major dimensions of girls' lives, including living arrangements, schooling, work, mobility, and marital patterns. Section IV reviews laws and policies that affect adolescent girls and summarizes the major programs that have been launched for this population. Section $\mathrm{V}$ concludes the report by suggesting research gaps, proposing policy initiatives, and providing tools for programmers to assess their own programs.

\footnotetext{
1 UNAIDS presents high and low estimates; the low estimates are presented above. The high estimates of HIV prevalence are 11.7 percent for girls aged 15-24 and 4.8 percent for boys in the same age group.

2 Distinct from engagement, girls may be "promised" as early as birth or childhood, typically to a particular family, rather than a specific boy or man.
} 


\section{BURKINA FASO COUNTRY PROFILE}

B urkina Faso is a landlocked West African country with a population of 13.9 million (Population Reference Bureau 2005). The country gained independence from France in 1960 and experienced repeated military coups in the 1970s and '80s, after which multiparty elections were established (CRR 1999). Its predominantly rural population is composed of more than 60 ethnic groups, the largest of which is the Mossi, representing more than half of the population. Other major groups include the Peul, the Gourmatché, and the Dioula. Sixty percent of the population is Muslim; smaller proportions are Catholic (23 percent), Protestant (5 percent), or practitioners of indigenous religions (10 percent) (INSD and ORC Macro 2004). ${ }^{3}$ French is the official language; however, local languages-Mooré, Dioula, and Fulfuldé-are commonly spoken by the majority of the population (CRR 1999).

A combination of drought, overgrazing, and rapid population growth have contributed to high rates of desertification and deforestation. Burkina's limited supply of arable land, combined with sparse and irregular

\section{A SNAPSHOT OF BURKINA FASO}

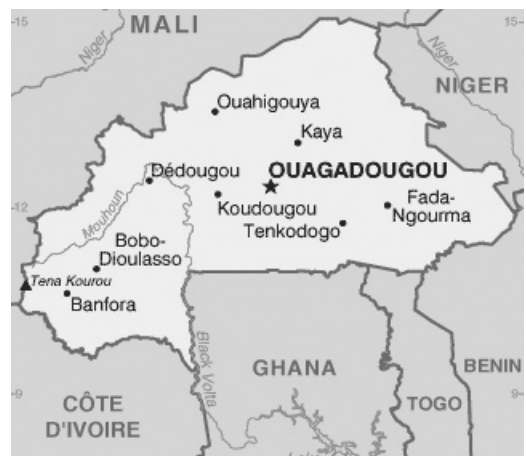

Capital city: Ouagadougou

Population: 13.9 million

Area: 105,792 square miles

Population per square mile: 132

Percent of population younger

than 15: 46

Life expectancy at birth, male: 42

Life expectancy at birth, female: 46

Percent living in urban areas: 17

Adult illiteracy rate: 87 percent

Percent of women aged 20-24 married by age 18: 52

Percent living below national poverty line: 45

Percent living on less than US\$2 a day: 81

Percent of population aged 15-49 living with HIV/AIDS: 2

Physicians per 100,000 people: 4

Sources: INSD and ORC Macro 2004; PRB 2005; UNDP 2005; UNAIDS 2006.

Map: Central Intelligence Agency 2004. rainfall, offer a fragile basis for agriculture and the livestock industry, which employ nearly 88 percent of the labor force (CIDA 2000). As a result of this instability, large proportions of men in the labor force migrate to the cities and neighboring countries looking for work; every year, several hundred thousand seasonal farmworkers seek employment in Côte d'Ivoire and Ghana. This migration is highly sensitive to external events. For example, the September 2002 attempted coup and ongoing violence in Côte d'Ivoire have prompted many thousands of Burkinabé to return home (US Department of State 2004).

Burkina Faso is one of the poorest countries in the world. With a gross national income (GNI) per capita of $\$ 360$ (compared with US\$600 for sub-Saharan Africa overall), the country is ranked 175 out of 177 countries on the United Nations' Human Development Indicators index (UNDP 2005; World Bank 2005). A structural adjustment program was launched in 1991 that consisted largely of trade liberalization, public enterprises sector reform, and fiscal reform (World Bank 2004). In 1997,

Burkina Faso qualified for support under the Heavily Indebted Poor Countries Initiative. According to the World Bank's assessment, the country's economy “continues to remain highly vulnerable to climatic conditions and international commodity prices" (World Bank 2004). Four major challenges were identified as hindering Burkina Faso's growth and development:

- Of the francophone countries in West Africa, Burkina Faso has one of the highest HIV/AIDS prevalence rates.

- Trade conditions in the cotton sector have reduced farmers' incomes, in part because of heavy agricultural subsidies in developed countries;

${ }^{3}$ These figures were obtained from the women's questionnaire, because questions about ethnicity and religion were not included in the household survey. 
- Unrest and instability in Côte d'Ivoire has disrupted trade, transport, and private-sector activity, and reduced or eliminated the remittance of thousands of Burkinabé workers;

- Rapid urbanization is increasing pressure on scarce natural resources, particularly water (World Bank 2004).

Indicators of health and development in the country are poor. Forty-nine percent of the population is without sustainable access to an improved water source (UNDP 2005), and half of the rural population lives at least $30 \mathrm{ki}-$ lometers from a health-care center (CRR 1999). Maternal and infant mortality rates remain high, and one out of three children younger than five is underweight for his or her age (UNDP 2005). Contraceptive prevalence is extremely low: 14 percent of married women aged 15-49 report that they are using any method of contraception, and a mere 9 percent are using a modern method (PRB 2005). Access to health care varies considerably by residence and economic status. Eighteen percent of deliveries to mothers in the poorest quintile versus 75 percent of deliveries to those in the richest quintile were aided by skilled attendants (UNFPA and PRB 2005). Although only 10 percent of Burkina Faso's population lives in its two largest cities, Ouagadougou and Bobo-Dioulasso, 54 percent of doctors, 57 percent of midwives, and 59 percent of pharmacists are located there, leaving the rest of the country severely underserved (Weil et al. 2003).
The Burkinabé government has passed legislation to prevent discrimination against girls and women on a range of issues. Laws often have little influence in rural communities, however, where traditional practices and customs limiting the rights of women persist. For example, civil law provides for equal property rights, whereas in many ethnic groups, women are prohibited from owning property. Likewise, under the Code of Persons and the Family, the surviving spouse may inherit from one-fourth of the partner's estate to the full estate, depending on the existence of surviving children, siblings, or parents. In contrast, most traditional systems not only neglect women's inheritance rights, but consider the woman, herself, as property, subject to inheritance upon her husband's death (CRR 1999). Under Burkinabé law, the minimum age at marriage is 20 for men and 17 for women. Both spouses must consent to the marriage and decide mutually whether the union is monogamous or polygamous (CRR 1999). Nonetheless, 52 percent of 2024-year-olds marry before their eighteenth birthday, and 36 percent of those marriages are polygamous (INSD and ORC Macro 2004). One area where the government has demonstrated its commitment beyond passing legislation is female genital cutting (FGC) (circumcision). Since 1996, more than 400 persons have been prosecuted for practicing FGC, and those convicted were subject to a significant fine and imprisonment of six months to three years. Despite these efforts, in the 2003 EDSBF, 65 percent of girls aged 15-19 reported having been circumcised (INSD and ORC Macro 2004). 


\section{THE SOCIAL AND ECONOMIC CONTEXT OF GIRLS' LIVES}

A Ithough considerable attention has been paid to adolescents' reproductive health, sexual behavior, and fertility, relatively little attention has focused on the broader contextual issues of their experiences such as living arrangements, schooling, work, and social mobility. These aspects of their lives not only reflect girls' status within their families and communities but also are critical to their well-being, social power, and decisionmaking in sexual relationships, marriage, and childbearing. This section reviews the available data on these key areas of Burkinabé girls' lives.

\section{Living arrangements}

As with the overall population of Burkina Faso, Burkinabé adolescents reside predominantly in rural areas (for example, 83 percent of 10-14-year-olds live in the countryside [INSD and ORC Macro 2004]). The common Western notion of adolescents is that they live within a nurturing and protective family unit that includes both parents. Available data show that this notion is often erroneous (see Figure 1). More than half of urban girls and more than one-fourth of rural girls aged 10-14 are living with only one or neither parent. Living arrangements differ for boys and girls in urban areas, where 55 percent of boys live with both parents, compared with only 45 percent of girls (INSD and ORC Macro 2004).

A considerable number of girls live with neither parent in both urban and rural areas (36 percent of urban girls and 13 percent of rural girls), a situation that warrants further inquiry and that may be a particular cause for concern. Although some of these girls are likely to be married and living in their marital homes, this number does not account for many of the girls who live apart from their parents. ${ }^{4}$ Alternatively, girls not living with their parents could be staying with extended family members in fostering situations. Although the assumption is often made that fostering benefits young people with opportunities they would not otherwise have, information drawn from other contexts suggests that girls are often fostered for their labor rather than for their benefit. ${ }^{5}$ More research is needed concerning the nature of fostering boys and girls who are likely to be vulnerable to exploitation and abuse.

\section{Schooling}

The benefits of education for girls are well established, and include increasing their economic productivity, improving their in health, delaying their age at marriage, lowering their fertility, and increasing their political participation (Population Council 1995). Educational

\footnotetext{
${ }^{4}$ Only 3 percent of urban girls are married by the age of 15.

${ }^{5}$ Data from both Ethiopia and Kenya suggest that many young people who are fostered supply domestic labor for their foster families, rather than gain entry to school or to paid employment. See Erulkar et al. (2002).
} 
TABLE 1 Percentage distribution of Burkinabé adolescents enrolled in school, by sex and age group, according to level of schooling, 2003

\begin{tabular}{lrrrrr}
\hline Sex/age & $\begin{array}{r}\text { Not in } \\
\text { school }\end{array}$ & Primary $^{\mathrm{a}}$ & Secondary $^{\mathrm{b}}$ & Higher & Total \\
\hline Girls & & & & & \\
$10-14$ & 71.4 & 25.6 & 3.0 & 0.0 & 100.0 \\
$15-19$ & 85.7 & 3.2 & 11.1 & 0.1 & 100.0 \\
Boys & & & & & \\
$10-14$ & 66.0 & 30.7 & 3.3 & 0.0 & 100.0 \\
$15-19$ & 81.8 & 4.5 & 13.6 & 0.0 & 100.0 \\
\hline
\end{tabular}

a Primary school in Burkina Faso consists of six grades.

${ }^{\mathrm{b}}$ Secondary school in Burkina Faso consists of seven grades. Source: INSD and ORC Macro (2004).

enrollment is extremely low in Burkina Faso for both sexes (see Table 1). Only 29 percent of girls aged 10-14 are enrolled in school, compared with 34 percent of boys. In later adolescence, enrollment drops to 14 percent for 15-19-year-old girls and 18 percent for boys in the same age group.

Although younger cohorts of girls have attained higher levels of education than older cohorts, girls are still less likely than boys to complete four or more years of school (see Table 2). Young people from urban areas and from relatively better-off households are more likely to be educated. Girls from the wealthiest households were more than nine times more likely to have completed at least four years of school, compared with girls from the poorest households. Similarly, girls living in ur-

TABLE 2 Percentage of adolescents and young adults who have completed more than four years of schooling and who have completed primary school, by sex, age groups, and socioeconomic status, Burkina Faso, 2003

\begin{tabular}{lrr}
\hline Sex/age & $\begin{array}{r}\text { Completed } \\
\text { 4+ years }\end{array}$ & $\begin{array}{r}\text { Completed } \\
\text { primary }\end{array}$ \\
Girls & & \\
$15-19$ & 27.4 & 21.9 \\
$20-24$ & 22.3 & 18.3 \\
$25-29$ & 16.1 & 13.8 \\
Socioeconomic status, ages 15-29 & & \\
Poorest 40 percent & 6.6 & 3.9 \\
Middle 40 percent & 14.1 & 10.1 \\
Richest 20 percent & 55.8 & 49.5 \\
Boys & & \\
15-19 & 35.1 & 27.1 \\
20-24 & 34.1 & 29.5 \\
$25-29$ & 29.2 & 25.2 \\
Socioeconomic status, ages 15-29 & & \\
Poorest 40 percent & 13.6 & 10.0 \\
Middle 40 percent & 27.8 & 20.8 \\
Richest 20 percent & 68.8 & 60.6 \\
\hline Source: INSD and ORC Macro (2004). & & \\
\hline
\end{tabular}

ban areas were more than seven times more likely than rural girls to have completed primary school (52 percent versus 7 percent, not shown).

Once married, girls' educational opportunities effectively end. Less than 1 percent of married girls aged 15-19 are in school, compared with 21 percent of unmarried girls.

Few Burkinabé adolescent girls are living with both parents and attending school. Only 19 percent of girls aged 10-14 reside with both parents and are enrolled in school, whereas nearly one of eight is living with neither parent and is not in school (INSD and ORC Macro 2004). The girls in the latter group warrant special consideration because they lack the basic protective structures that are considered fundamental to a secure adolescence.

\section{Work}

Despite international conventions protecting children and young people from work that interferes with their development, many children are in the labor force, often beginning at early ages. Safe and appropriate livelihood opportunities can offer benefits to adolescent girls by strengthening their economic and social capacities, helping them to gain autonomy, and improving their future prospects for participation in the labor market (Population Council 2005). Moreover, girls' wages can add desperately needed resources to household income, and raise their status in the family. Work is a common feature of adolescent girls' lives in Burkina Faso; three out of four 15-19-year-old girls are currently working. Work status varies greatly by area of residence and to a lesser degree by marital status (see Figure 2). Among married

FIGURE 2 Percentage of girls aged 15-19 currently working, by marital status and residence, Burkina Faso, 2003

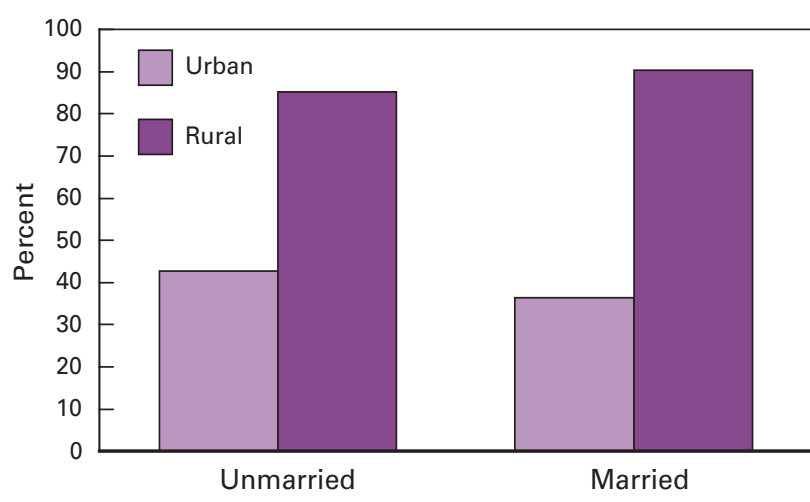

Source: Population Council tabulations based on EDSBF-III data (INSD and ORC Macro 2004). 
girls, those in rural areas are more than two times more likely than those in urban areas to be working.

Of 15-19-year-old girls who work, 73 percent of urban girls and 16 percent of rural girls report receiving cash or a mixture of cash and in-kind remuneration for their work. If we look at whom these girls are working for, this sort of payment makes sense: most rural girls are working for a family member and most urban girls are working for a nonrelative or are self-employed (see Figure 3). In both urban and rural areas, however, married girls are more likely than unmarried girls to be self-employed.

Calvès and Schoumaker (2004) analyzed data from the 2000 nationally representative Migration Dynamics, Urban Integration and Environment Survey of Burkina Faso (MDUIE) to examine the changes that employment of urban young people has undergone over the past 20 years. They found evidence of increasing unemployment and informalization of employment of the young in urban Burkina Faso, especially among educated young people. The majority of young women continue to start working in the informal sector by selling food items. Service jobs (such as domestic service or hairdressing, typically less profitable and more vulnerable jobs) currently are attracting more young women than in the past, however. Although uneducated young people are entering the labor force at about the same age as they used to do, educated males are entering at a later age. This change may reflect both the lengthening of their schooling and their increased difficulties in finding jobs after leaving school.

FIGURE 3 Percentage of girls aged 15-19, by residence and marital status, according to category of employer, Burkina Faso, 2003

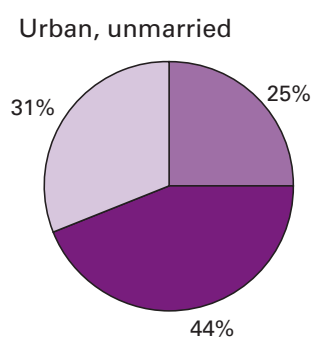

Rural, unmarried

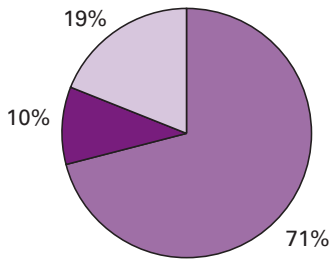

Urban, married

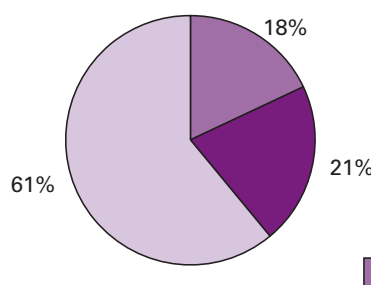

For family member

For nonrelative

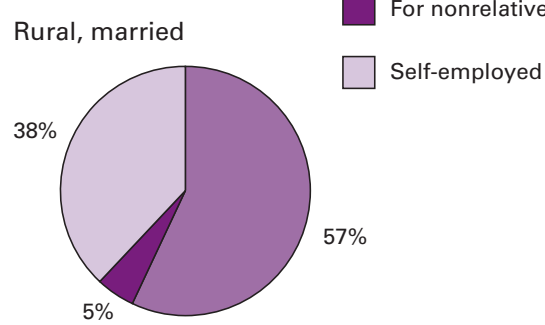

Early marriage is a phenomenon that affects girls disproportionately; whereas the median age at marriage for girls is 17.7 years, for boys it is 25.8 years. The majority of Burkinabé girls are married during adolescence. Nearly two-thirds of rural girls (62 percent) aged 20-24 reported that they were married by age 18 . Although the legal age at marriage is 17 for girls in Burkina Faso, some are married much earlier; 6 percent of rural girls are married before their fifteenth birthday. To gain a better understanding of the marital process and the restrictions girls face upon marriage, the Population Council conducted a qualitative study in two rural villages where early marriage is prevalent (see box on page 8).

The prevalence of early marriage varies considerably by urban-rural residence, socioeconomic status, ethnicity, religion, and educational attainment (see Table 3). Rural girls are almost three times more likely than urban girls to be married by the age of 18. Early marriage is prevalent among the Peul; nearly one out of five girls is married before her fifteenth birthday. A strong relationship exists as well between educational attainment and marriage. Girls with zero to three years of education are about nine times more likely than girls with eight or more years of education to be married by age 18 .

A woman's status in a polygynous marriage is affected by her position in relation to her husband and by her position vis-à-vis her cowives in terms of age, education, and family background (Gage-Brandon and Meekers 1993). An adolescent who is married polygamously is, therefore, likely to be of low social status because she is not only one among other wives, but often a junior wife in the family. Although the practice is declining, more than onethird of marriages among 20-24-yearold girls are polygamous (as shown in Table 3). Not surprisingly, polygamy is more prevalent in rural than in urban areas (40 percent of rural marriages, compared with 16 percent of urban marriages). Child marriages are more likely to be polygynous; 46 percent of women who married before age 18 are in polygynous unions, compared with 14 percent of women who married at or after age 18 (not shown) (Clark et al. 2006).

Large differences in age between a young woman and her husband create a power imbalance in the marriage.

Source: Population Council tabulations based on EDSBF-III data (INSD and ORC Macro 2004). 


\section{POPULATION COUNCIL MARRIAGE STUDY}

$\mathrm{T}$ ypically, married girls have had little schooling, know little about reproductive health, and experience unsafe and often unwanted sexual relations with a spouse who may be much older. They are also likely to bear a child before they are physically and psychologically prepared to do so. Despite the importance of the marital transition in a girl's life, and the role that early marriage plays in limiting her self-realization and participation in community life, little research has been conducted on this issue. In 2001, the Population Council conducted a qualitative study in two rural villages of Gourma province, Koaré and Natiaboani. In-depth interviews were conducted with 76 married girls aged 15-19, 25 unmarried girls aged 15-19, and 10 partners of married girls. The key findings are summarized below.

The majority of the 101 adolescent girls who were interviewed were Mossi and Muslim. Few had attended school, and only one had reached secondary school. Almost half of the married girls in the sample were married into polygynous unions, most frequently as the second spouse. Although some married girls did not know their husbands' ages, half of those who knew it reported a spousal age difference of 11 years or more. Twenty-one percent reported this difference as 21 years or more.

\section{MARRIAGE ARRANGEMENTS}

- Among the 75 married adolescent girls in the study, 35 reported that they chose their partner. Although other considerations were mentioned, respondents cited love as a primary motivation for their choice of spouse.

- For those girls whose families arranged their marriages, arrangements were made according to the "gift" system, whereby either one girl is exchanged for another, or a girl is given as a kind of reward. Exchanges of girls occur between families or villages. The exchange of girls may not occur simultaneously; a family can "owe" another family a girl. Girls may be promised at birth (and in some instances prior to birth) or in childhood. A less common strategy is one in which a girl is given to a family in return for goods and services or to secure a relationship between the two families.

\section{THE MARITAL PROCESS}

- In the study areas, the legal age at marriage was largely ignored and practices were based on social, physical, and economic considerations. The majority of the girls in the sample were married between the ages of 14 and 17; two girls were married at age 11, and four girls at 12 or 13 .

- For some arranged marriages, families avoided the girl's potential rejection of the choice of spouse and/or the timing of the marriage by not informing the girl of the decision until the day of the wedding.

- In the period leading up to their marriage, girls received instruction on housework, child care, and the appropriate (submissive) behavior to adopt toward their husbands and in-laws, and experienced tighter restrictions on their mobility and relationships.

- During the engagement period, future partners (especially those that chose each other) visited and exchanged gifts, and the girl sometimes cooked for her fiancé or washed his clothes. Although premarital sex occurs rarely in these villages, six girls reported that they had experienced sexual relations with their future spouses, generally without protection.

\section{ADOLESCENT GIRLS' EXPERIENCE OF MARRIED LIFE}

- A married girl generally lived in a compound with her husband and his family, including his parents, any cospouses, and sometimes brothers and sisters and their spouses. The married girls described their mothers-inlaw as major figures in their lives; the mother-in-law assigns daily household duties, acts as a resource for advice/information, negotiates with her son if difficulties arise, and is the main authority if the husband and father-in-law are not present.

On my wedding day, my mother and my father gave me the following advice: 'Once you are at your busband's bome, you must not disrespect your mother-in-law or father-in-law; you must care for them the same way you would care for your parents; you must respect your brotber-in-law as much as your busband.' And they told me that if I were behaving badly and my busband brought me back to them, they would not accept me at bome anymore, and $I$ would be a renegade in my own family. —MOSSI GIRL, POLYGYNOUS MARRIAGE, I 9 YEARS OLD 
- Some young brides reported that they had no one with whom to discuss their problems, because their natal families were unsympathetic and stressed obedience.

- In general, the mobility of married girls was highly restricted, particularly if they were married without their consent or had no children. Husbands and their families feared that a childless wife who had been forced into marriage might flee.

- A girl's relationships with her own friends and family were also subject to permission from her husband and in-laws. Acceptable relationships were generally limited to parents, members of her husband's family, married women of the same age, and women who were friends of her husband.

- More than half of the married girls interviewed worked, mostly in the fields, making handicrafts, or selling food. Married girls used their income for personal items such as soap or body lotion and to contribute to family expenses, including the costs for schooling their children.

\section{THE MARITAL RELATIONSHIP}

- Married girls reported having little communication with their husbands. Husbands rarely asked their wives' opinion on matters other than cooking or clothing. Some girls developed strategies for expressing their opinions, such as speaking with their husbands at a quiet time using patience and gentleness to offer their own views.

- A high proportion of married girls in Gourma reported experiencing domestic violence (physical, sexual, verbal, and economic). They reported verbal abuse most frequently, followed by sexual violence.

- Married adolescent girls reported being able to refuse sex when they were menstruating, pregnant and near delivery, breastfeeding, and when they were sick. Only two girls reported refusing sex because they "did not want it." Refusing sex, however, often resulted in conflicts or violence.

- Husbands were expected to initiate sexual activity. The majority of married adolescent girls disclosed that they were unable to demonstrate sexual desire to their husband, although a few described strategies such as preparing a good meal to attract his attention, or dressing up with a short loincloth.

\section{REPRODUCTIVE HEALTH KNOWLEDGE} AND BELIEFS

- Approximately 95 percent of the girls surveyed reported ignorance of sexually transmitted infections (STIs) other than HIV/AIDS. A minority reported that they had heard talk of STIs on the radio, but they could not be specific.

- A majority of girls believed that men are responsible for using protection against HIV/AIDS, arguing that men, rather than women, are promiscuous. Girls claimed that men were more likely than women to become infected because men are mobile and because men's extramarital relationships are socially accepted.

- Opinions were divided regarding condom use: Girls had a positive perception of condom use within marriage as a contraceptive method. However, most married and unmarried girls had a negative perception of condom use within marriage as protection against infections, regarding such use as a sign of mistrust between partners.

\section{PREGNANCY AND CHILDBEARING}

- Girls in the Gourma study became pregnant soon after marriage; they felt pressure to prove their fertility and desired to raise their social status. Only two girls confided that they did not want to be pregnant as soon as they were married because they wanted to enjoy their youth.

I desired this pregnancy because once married, what is a woman's value if she does not bear a child?

-MOSSI GIRL, I9 YEARS OLD

- Most adolescent mothers reported receiving prenatal care at a clinic. Prenatal visits were irregular, however, and often motivated by a specific medical need rather than for preventative care.

- Most deliveries took place at home because of the long distance to the nearest health center, the lack of money to pay for medication and hospital care, the poor quality of the service provided at hospitals and clinics, and the lack of female providers to attend deliveries.

- Married adolescent girls in Koaré expressed a strong desire for a conveniently located health center to reduce the number of home deliveries and mentioned specifically the need to reduce the risk of infection resulting from poor hygiene.

Note: For a full report of this study, see Saloucou et al. (2002). 


\section{COMMUNITY MAPPING EXERCISE}

$\mathrm{T}$ o complement the findings of the diagnostic study of the marital process and the conditions of married Burkinabé girls' lives, the Population Council conducted a community-mapping exercise using a participatory learning activity (PLA). (For more information, see Chong et al. 2006.) In January 2003, data were collected from three groups of 10-19-year-olds (unmarried boys, unmarried girls, and married girls) in Natiaboani and Koaré villages in Gourma province. Participants identified acceptable places for adolescents to gather; discussed what activities are currently available at each location and proposed additional services that could be introduced; and considered where future activities could be placed to make them accessible to different subgroups of adolescents.

Diagrams were created to represent the findings of the exercise; participants designed the symbols and drawings used to represent the places on the map; the oval symbolizes the limits of the village (see below). Key observations include:

\section{COMMUNITY NORMS - WHERE BOYS AND GIRLS GO}

- Girls are limited to traditional spaces such as water wells, places of worship, marketplaces, and traditional women's groups. The events that both girls and boys may attend include marriages, baptisms, and funerals.

- Married girls are closely supervised and limited in their movement in the village, in their access to information, and in their participation in leisure activities. Their lives are focused on maternity and management of the household, and their mobility is constrained to those areas related to those two concerns.

- Unmarried adolescent boys have almost limitless freedom. They have access to leisure activities and sports centers and are well informed about services that are available in the community.

- Spaces for leisure activities are considered necessary for boys' development into wellrounded individuals, whereas these spaces are considered haz-
Where can unmarried adolescent boys go? Black: Where they go White: Where they do not go

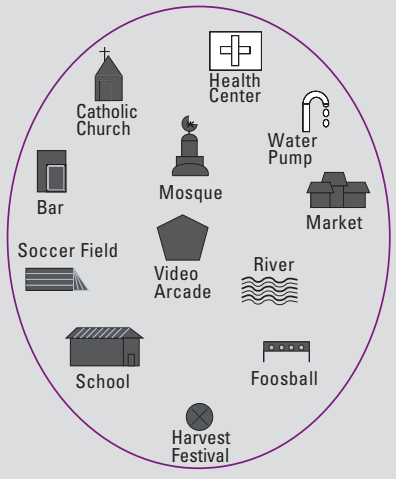

ardous and inappropriate for adolescent girls, either married or unmarried.

\section{USING EXISTING INSTITUTIONS AND ORGANIZATIONS}

- The existing organizations and collectives in the communities primarily serve men. The few women's organizations are composed of adult women only; they do not include adolescents.

- Government administrative facilities in the villages concentrate on agricultural and livestock training and activities.

- Health centers are frequented primarily by married women seeking prenatal care and child immunizations.

\section{POTENTIAL WAYS AND PLACES TO REACH ADOLESCENTS}

- Married adolescent girls have little free time available to obtain access services or participate in reproductive health training. Therefore, such activities are most likely to reach them if they are conducted in the girls' homes or when they visit a health center to obtain prenatal care or vaccinations.

- Girls who were surveyed for the mapping project indicated that educational activities might be held at celebrations and baptisms. Spaces and events should also be identified that allow for individual consultations, however, where girls' confidentiality and anonymity will be respected.

- Possible entry points identified for reaching married adolescent girls include health centers and religious spaces (if religious officials support the program).
Where can unmarried adolescent girls go? Purple: Where they go

White: Where they do not go

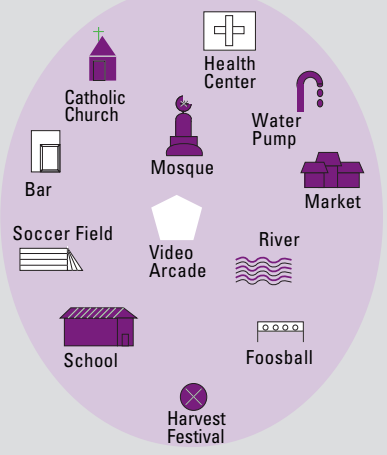

Where can married adolescent girls go? Purple: Where they go White: Where they do not go

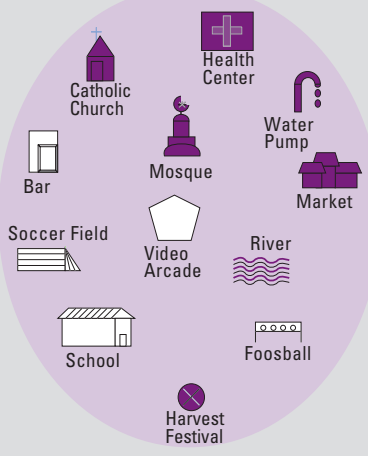


TABLE 3 Percentage of Burkinabé girls aged 20-24 who were married by age 15 and age 18 , by selected sociodemographic variables, 2003

\begin{tabular}{|c|c|c|c|}
\hline & $\begin{array}{r}\text { Married } \\
\text { by } 15\end{array}$ & $\begin{array}{r}\text { Married } \\
\text { by } 18\end{array}$ & $\begin{array}{c}\text { Polygynous } \\
\text { marriages }\end{array}$ \\
\hline \multicolumn{4}{|l|}{ Residence } \\
\hline Urban & 2.6 & 22.0 & 15.5 \\
\hline Rural & 6.2 & 62.3 & 39.5 \\
\hline \multicolumn{4}{|c|}{ Household wealth index } \\
\hline Poorest & 9.3 & 73.2 & 25.3 \\
\hline Poorer & 5.7 & 62.5 & 36.4 \\
\hline Middle & 7.1 & 61.3 & 46.3 \\
\hline Richer & 3.3 & 53.3 & 45.3 \\
\hline Richest & 2.1 & 23.6 & 20.4 \\
\hline \multicolumn{4}{|l|}{ Ethnicity } \\
\hline Dioula & 5.0 & 43.4 & 30.4 \\
\hline Gourmatché & 6.0 & 71.0 & 26.1 \\
\hline Lobi & 16.1 & 52.7 & 36.8 \\
\hline Mossi & 2.6 & 49.4 & 40.0 \\
\hline Peul & 17.9 & 73.6 & 23.1 \\
\hline \multicolumn{4}{|l|}{ Religion } \\
\hline Muslim & 5.1 & 56.6 & 38.9 \\
\hline Catholic & 3.9 & 29.5 & 19.7 \\
\hline Traditional & 6.1 & 70.3 & 45.3 \\
\hline Protestant & 6.0 & 53.0 & 25.3 \\
\hline None & 7.9 & 64.9 & 52.8 \\
\hline \multicolumn{4}{|c|}{ Education (years of schooling) } \\
\hline $0-3$ & 6.0 & 61.1 & 38.7 \\
\hline $4-7$ & 5.3 & 34.6 & 18.0 \\
\hline $8+$ & 0.4 & 6.8 & 13.0 \\
\hline TOTAL & 5.2 & 51.9 & 35.8 \\
\hline
\end{tabular}

Source: Population Council tabulations based on EDSBF-III data (INSD and ORC Macro 2004).

As Abadian (1996: 1,797) noted, “One may argue that in societies where power to make decisions and control of resources lies with those who are senior in age, the wider the age gap between spouses, the more the wife will be subject to age bias and not just gender bias in the curtailment of her autonomy by her husband and his family." Indeed, some studies have used spousal age difference as an indicator of, or proxy for, women's autonomy. In Burkina Faso, age differences between a bride and her husband often are great, especially in cases where the girl is her husband's second or third wife. Typically the younger the bride, the greater the spousal age disparity. Among 25-29-year-olds married before they were 18, the mean spousal age difference is 12.1 years, whereas girls who married at or after age 18 were 10.4 years younger than their husbands, on average (Clark et al. 2006). Age differences in polygamous unions are striking: Girls who are married polygamously are, on average, 20.5 years younger than their husbands, whereas the age difference among monogamously married women is 8.0 years (INSD and ORC Macro 2004).

\section{Sexual and reproductive health}

Although the sexual activities of unmarried adolescents have been the target of numerous programs and research studies, in Burkina Faso, as in many other countries in the developing world, most sexual activity among adolescent girls takes place within marriage. Seventy-seven percent of 15-19-year-old girls who are sexually active are married. Although they are in the minority, a substantial number of unmarried girls have had sex; 25 percent of unmarried girls aged 15-19 report ever having had sex, and 8 percent report being sexually active. A national survey of adolescents conducted by the Alan Guttmacher Institute (2004) found substantial levels of transactional and coerced sex among young girls. More than one of three sexually active girls aged 12-19 (excluding those who were married or in union) reported receiving money or other items (primarily clothes or jewelry) in exchange for sex. In contrast, only 5 percent of boys reported engaging in transactional sex (Guiella and Woog 2006). The national survey also found that 18 percent of 15-19-year-old girls reported that they had experienced unwanted touching, and 8 percent reported having experienced coerced sex.

Not only are married girls more likely than unmarried girls to be sexually active, they have fewer means of obtaining reproductive health information (see Table 4). Unmarried girls are more likely than married girls to be in school, to listen to the radio, to watch television, and to read the newspaper (Clark et al. 2006). Accordingly, unmarried girls are more knowledgeable about HIV/ AIDS, and appear to be more successful in negotiating safer sex with their partners (as shown in Table 5).

Most girls, regardless of marital status, have heard of HIV/AIDS, but fewer are familiar with how the infection is transmitted or the progression of the disease. Almost half of the married girls interviewed did not know that HIV could be transmitted from mother to child, which is especially worrisome because married girls become mothers very quickly in this setting. Even among those who do not wish to become pregnant in the next

TABLE 4 Percentage of girls aged 15-19, by their means of obtaining reproductive health information, according to their marital status, Burkina Faso

\begin{tabular}{lc}
\hline Exposure variable & Unmarried \\
\hline Currently enrolled in school & $20.4^{* * *}$ \\
Listens to radio daily & $23.8^{* *}$ \\
Watches television weekly & $40.0^{* * *}$ \\
Reads newspaper weekly & $10.9^{* * *}$ \\
${ }^{* *}$ Significant at $\mathrm{p} \leq 0.01 ;{ }^{* * *} \mathrm{p} \leq 0.001$. & \\
Sources: Clark et al. (2006) and Population Council analyses of EDSBF-III \\
(INSD and ORC Macro 2004).
\end{tabular}


TABLE 5 Percentage of girls surveyed aged 15-19 who have heard of HIV/AIDS, and of these, percentage who have some knowledge of transmission and prevention, Burkina Faso, 2004

\begin{tabular}{lrccc}
\hline Girls aged 15-19 & $\begin{array}{r}\text { Has heard of } \\
\text { HIV/AIDS }\end{array}$ & $\begin{array}{r}\text { Knows that a healthy-looking } \\
\text { person can have HIV/AIDS }\end{array}$ & $\begin{array}{r}\text { Knows that HIV can be trans- } \\
\text { mitted from mother to child }^{\text {a }}\end{array}$ & $\begin{array}{r}\text { Knows one way to } \\
\text { avoid HIV infection }^{\text {a }}\end{array}$ \\
\hline Unmarried (all) & 92.0 & 61.7 & 59.4 & 62.8 \\
Unmarried, sexually active & 98.1 & 71.4 & 69.9 & 78.7 \\
Married & 92.3 & $54.2^{* * *}$ & $54.1^{*}$ & $56.7^{*}$ \\
\hline
\end{tabular}

${ }^{*}$ Significant at $p \leq 0.05 ;{ }^{* * *} p \leq 0.001$ (significance tests compare married girls with all unmarried girls). $\quad$ na $=$ Not available.

aThese calculations exclude those who have not heard of HIV/AIDS

Source: Population Council analyses of EDSBF-III (INSD and ORC Macro 2004).

two years, married girls are three times more likely than sexually active unmarried girls to have had unprotected sex the previous week (see Table 6).

The Guttmacher survey also examined the sources of reproductive health information available to adolescents. Although the mass media were the primary sources of information about HIV/AIDS for boys and girls (66 percent and 60 percent, respectively), girls were more likely than boys to obtain such information from family members (39 percent versus 28 percent), and boys were more likely than girls to obtain such information from friends (30 percent versus 20 percent). Few adolescents reported exposure to sex education in school; fewer than 20 percent of adolescents attended a school where such a curriculum was offered, and approximately 15 percent attended the course (Guiella and Woog 2006).

Research conducted by the Burkinabé Association for Family Well-Being (ABBEF) in northern Burkina Faso indicates some of the most pressing of adolescents' reproductive health concerns. Among the 366 young people aged 10-24 that were surveyed in ten rural villages in Yatenga, unwanted pregnancy was the most commonly cited reproductive health problem (53 percent). Premarital pregnancy carries intense social stigma for the girl and her family. Yet few respondents in the ABBEF study were aware of contraceptive methods, and virtually no one in the 10-19 age group mentioned condoms. Instead, abstinence was cited as the primary strategy for preventing pregnancy. Boys and girls alike tended to blame unwanted pregnancy on the girls' having multiple sexual partners, rather than on lack of protection (PIWH 2002). The stigma against premarital pregnancy in Burkina Faso leads many girls to seek abortions, typically under unsafe conditions, because the procedure is illegal (with a few exceptions in cases of rape or threat to the mother's health). Accurate statistics are difficult to obtain, but some studies suggest that abortion is common among adolescent girls: one study conducted in the three largest cities found that more than one of four girls aged 10-25 who had been pregnant had undergone an abortion, and 42 percent knew someone who had had an abortion. Another study conducted in Ouagadougou found that 22 percent of respondents aged 15-19 had terminated a pregnancy (AGI 2004).

The reproductive health knowledge and behavior of married girls in Burkina Faso vary widely by area of residence (as shown in Table 7). For example, 74 percent of married girls aged 15-19 living in urban areas versus 52 percent of those in rural areas know that a healthylooking person can be infected with HIV. Moreover, urban married girls are more than seven times more likely than rural married girls currently to be using a modern method of contraception.

Child marriage may elevate girls' risk of HIV infection for several reasons: (1) husbands of child brides tend to be older than the boyfriends of unmarried girls, and, therefore, have a greater lifetime risk of carrying sexually transmitted infections such as HIV; (2) a considerable age gap may exaggerate the power imbalance in the marital relationship and inhibit communication about safe sex; (3) marriage is almost always accompanied by increased frequency of sexual relations and strong pressure to bear children, ruling out the use of condoms. In Burkina Faso, married girls are significantly more likely than unmarried girls to have had unprotected sex in

TABLE 6 Percentage of girls surveyed aged 15-19, by marital status and desire to have a child, according to contraceptive use, discussion of family planning, and recent sexual activity, Burkina Faso, 2006

\begin{tabular}{|c|c|c|c|c|}
\hline & $\begin{array}{l}\text { Ever used a modern } \\
\text { contraceptive method }\end{array}$ & $\begin{array}{l}\text { Currently using a modern } \\
\text { contraceptive method }\end{array}$ & $\begin{array}{l}\text { Ever discussed family } \\
\text { planning with partner }\end{array}$ & $\begin{array}{l}\text { Had unprotected sex during } \\
\text { week prior to interview }\end{array}$ \\
\hline Unmarried (ever had sex) & 50.3 & 35.8 & 0.9 & $9.9^{\mathrm{b}}$ \\
\hline Sexually active, does not want child now & na & na & na & 10.0 \\
\hline Married & 12.0 & 4.4 & 9.5 & 45.2 \\
\hline Does not want child now & na & na & na & 29.9 \\
\hline
\end{tabular}


TABLE 7 Percentage of married girls aged 15-19, by area of residence and marriage type, according to selected indicators of reproductive health knowledge and behavior, Burkina Faso

\begin{tabular}{|c|c|c|c|c|c|}
\hline Married girls aged 15-19 & $\begin{array}{l}\text { Knows that fertile period } \\
\text { occurs in mid-cycle }\end{array}$ & $\begin{array}{r}\text { Knows a modern } \\
\text { method of contraception }\end{array}$ & Has heard of HIV/AIDS & $\begin{array}{r}\text { Knows that a } \\
\text { healthy-looking person } \\
\text { can have HIV/AIDS }\end{array}$ & $\begin{array}{r}\text { Knows that HIV can } \\
\text { be transmitted from } \\
\text { mother to child }\end{array}$ \\
\hline \multicolumn{6}{|l|}{ Residence } \\
\hline Urban & 16.9 & 96.6 & 98.9 & 73.9 & 77.3 \\
\hline Rural & 17.3 & 81.5 & 91.5 & 51.8 & 51.3 \\
\hline \multicolumn{6}{|l|}{ Marriage type } \\
\hline Monogamous & 18.0 & 82.2 & 91.5 & 56.3 & 57.8 \\
\hline Polygynous & 15.4 & 85.0 & 94.4 & 49.6 & 46.2 \\
\hline \multirow[t]{2}{*}{ Total } & 17.2 & 83.0 & 92.3 & 54.2 & 54.1 \\
\hline & $\begin{array}{l}\text { Ever used a modern } \\
\text { contraceptive method }\end{array}$ & $\begin{array}{l}\text { Currently using a modern } \\
\text { contraceptive method }\end{array}$ & $\begin{array}{l}\text { Ever discussed family } \\
\text { planning with partner }\end{array}$ & Ever been pregnant & Ever given birth \\
\hline \multicolumn{6}{|l|}{ Residence } \\
\hline Urban & 43.8 & 20.2 & 13.6 & 58.0 & 40.4 \\
\hline Rural & 8.4 & 2.7 & 9.0 & 65.1 & 49.2 \\
\hline \multicolumn{6}{|l|}{ Marriage type } \\
\hline Monogamous & 14.1 & 5.9 & 10.3 & 65.4 & 50.6 \\
\hline Polygynous & 6.7 & 0.8 & 7.5 & 62.2 & 43.2 \\
\hline Total & 12.0 & 4.4 & 9.5 & 64.4 & 48.3 \\
\hline
\end{tabular}

the week prior to the interview (45.2 percent versus 2.4 percent, respectively) (Clark et al. 2006).

The Guttmacher survey of adolescents found that although a significant proportion (20 percent of girls and 19 percent of boys) of 15-19-year-olds believe they are at severe risk of becoming infected with HIV, many are not aware of voluntary counseling and testing (VCT) services. Younger adolescents are less likely to know about VCT; among girls who have heard of HIV, 53 percent of 12-14-year-olds and 38 percent of 15-19-year-olds did not know that a test could determine one's HIV status (Guiella and Woog 2006).

Childbearing begins soon after marriage and is a dangerous proposition for Burkinabé girls and young women. Just over half ( 55 percent) of births to women younger than 20 are attended by skilled personnel during childbirth (PRB 2006). Of 125 countries ranked in Save the Children's Mothers' Index, which compares the well-being of mothers and children, Burkina Faso ranked next to last. ${ }^{6}$ (Save the Children 2006). According to the EDSBF-III, more than one of four married girls gave birth before their eighteenth birthdays (see Table 8). Early childbearing is especially common among the Peul and Gourmatché ethnic groups.

\footnotetext{
6 The index is comprised of six indicators measuring the status of women (lifetime risk of maternal mortality, percentage using a modern contraceptive, percentage of births attended by trained personnel, percentage of pregnant women with anemia, adult female literacy rate, and participation of women in national government) and of four indicators of the well-being of children (infant mortality rate, gross primary-school enrollment ratio, percentage of population with access to safe water, and percentage of children younger than five suffering from moderate or severe malnutrition).
}

TABLE 8 Percentage of married Burkinabé girls aged 20-24 who gave birth by age 15 and by age 18 , by selected sociodemographic variables

\begin{tabular}{|c|c|c|}
\hline Variable & By 15 & By 18 \\
\hline Total married & 1.9 & 28.4 \\
\hline \multicolumn{3}{|l|}{ Residence } \\
\hline Urban & 0.7 & 19.5 \\
\hline Rural & 2.1 & 30.0 \\
\hline \multicolumn{3}{|l|}{ Wealth index } \\
\hline Poorest & 1.5 & 37.5 \\
\hline Poorer & 2.2 & 30.8 \\
\hline Middle & 2.7 & 28.8 \\
\hline Richer & 1.5 & 23.5 \\
\hline Richest & 0.6 & 19.8 \\
\hline \multicolumn{3}{|l|}{ Ethnicity } \\
\hline Mossi & 1.1 & 22.7 \\
\hline Gourmatché & 2.3 & 40.7 \\
\hline Peul & 4.9 & 51.0 \\
\hline Dioula & 1.1 & 27.2 \\
\hline Lobi & 4.5 & 35.2 \\
\hline \multicolumn{3}{|l|}{ Religion } \\
\hline Muslim & 1.7 & 29.5 \\
\hline Catholic & 2.2 & 20.3 \\
\hline Traditional & 1.2 & 27.3 \\
\hline Protestant & 6.0 & 39.8 \\
\hline None & 2.8 & 38.9 \\
\hline \multicolumn{3}{|l|}{ Marriage type } \\
\hline Monogamous & 1.6 & 27.2 \\
\hline Polygynous & 2.4 & 30.6 \\
\hline \multicolumn{3}{|c|}{ Years of schooling completed } \\
\hline $0-3$ & 2.0 & 30.5 \\
\hline $4-7$ & 1.9 & 17.4 \\
\hline $8+$ & 0.0 & 9.1 \\
\hline \multicolumn{3}{|c|}{$\begin{array}{l}\text { Note: Only births that occurred in the same year as the marriage or later } \\
\text { were counted. } \\
\text { Source: Population Council analyses from EDSBF-III (INSD and ORC Macro } \\
\text { 2004). }\end{array}$} \\
\hline
\end{tabular}




\section{GIRLS' PARTICIPATION IN THE DEVELOPMENT PROCESS}

$\mathrm{D}$ uring the past 15 years, the government of Burkina Faso has increasingly recognized the needs of adolescents, highlighting them as a target group in national policies and programs and creating institutional structures to coordinate activities to serve this group. The International Conference on Population and Development held in Cairo in 1994 (ICPD) was particularly influential in helping policymakers and program planners identify adolescents' sexual and reproductive health as a priority.

\section{Existing policies and legal frameworks}

Brief summaries of the significant pieces of legislation and policies that have important implications for adolescents are given below.

The National Population Policy (NPP) was adopted in 1990. The policy's specific objectives included:

- making population information more widely available, especially to adolescents, by 2005 , to enable individuals to become more responsible parents;

- promoting equal access to education for girls through sensitization campaigns aimed at parents;

- promoting women's access to paid work; improving women's productivity; and easing women's tasks in the home; and

- undertaking actions to eliminate oppressive social institutions and cultural practices that discriminate against women (CRR 1999).

The NPP was updated in 2000, and includes objectives that directly and indirectly address adolescents' health (Weil et al. 2003). The new policy aims to "promote greater use of reproductive health services particularly among women, adolescents, and youth," and recommends the "promotion of reproductive health integrated services or youth-oriented reproductive health services, community involvement in the implementation of youth structures, and use of peer [education] techniques to sensitize and inform youth"(Calvès 2002:8).
The National Multisectoral Plan to Combat STIs/ AIDS (1994), proposes specific activities for adolescents, including: creation of an information, counseling, and STI screening center for young people in Ouagadougou; support of an "IEC-Youth" (information, education, and communication) campaign in the regions; and the creation of school magazines on STIs/AIDS (Calvès 2002).

The Strategic Plan for Reproductive Health (1998) identifies four key components: safe motherhood, the elimination of obstacles to improving reproductive health, the prevention and treatment of infectious and noninfectious conditions of the reproductive tract, and adolescents' sexual and reproductive health (CRR 1999). The Plan recognizes that the "health of youth and adolescents is now a major concern for the government," and emphasizes a range of $\mathrm{ARH}$ issues that include early childbearing, unintended pregnancies, illegal abortions, exposure to STIs including HIV, lack of information about sexuality, and inadequate reproductive health services (Calvès 2002).

The National Youth Health Program (1998) targets 10-24-year-olds, and includes among its objectives:

- increasing the level of knowledge about young people's health among target groups in order to encourage health-promoting behaviors (producing posters, brochures, t-shirts, radio shows, and plays, and promoting parent-child discussions);

- increasing the accessibility of health services;

- offering high-quality services in health facilities (at least 10 percent of existing basic health and referring facilities offer reproductive health services to adolescents; infirmaries are open in schools; existing youth centers are outfitted with modern equipment; and health practitioners receive additional training);

- promoting research in various domains of adolescents' health and nutrition; and

- creating a legal environment favorable to the promotion of good health among adolescents and young people (evaluation and revision of existing legal texts; and dissemination of legal provisions at various levels of the health-service system). 
Family-life education, referred to as population education, is a strategy preferred by the government, which implemented a national program as early as 1987. Population education is integrated into secondaryschool curricula, and the government is extending it to primary school as well. Planners are also experimenting with targeting young people in the informal education system, reaching adolescents through agricultural training centers and literacy centers (Calvès 2002). The goals of the National Family Life Education Policy include: raising awareness about the physical, psychological, and emotional changes young people experience; educating adolescents about their rights and responsibilities and about prevailing social norms; and emphasizing the importance of responsible childbearing (CRR 1999).

The National Action Plan For Girls' Education (1994-2000) aims to reduce by one-third the gender discrepancy in school-enrollment rates. The government also revised school curricula with the special concerns of girls in mind, eliminated sexist stereotypes in school textbooks, and promoted gender awareness among teachers and other staff (CRR 1999).

Female genital cutting (FGC) is widely practiced in Burkina Faso, with almost two of three girls undergoing the procedure (more than half by age five) (INDS and ORC Macro 2004). The government has taken several measures to combat FGC: In 1990, the National Committee to Prevent the Practice of Female Circumcision (CNLPE), an autonomous agency within the Ministry of Social Welfare and the Family, was established by presidential decree (CRR 1999). This committee oversees activities to prevent FGC throughout the country, including education, research, and evaluation (Rahman and Toubia 2000). The Strategic Action Program (2001-05) set forth the objective of eliminating FGC before 2015 by enforcing relevant legal texts, conducting operations research, conducting advocacy campaigns among the general public and community leaders, and training FGC practitioners for new occupations (Calvès 2002). Since 1997, under the Penal Code, FGC is punishable by six months to three years of imprisonment and/or a fine of 150,000-900,000 CFA francs (US\$239-1,433); harsher penalties are incurred if the victim dies (five to ten years of imprisonment). More than 400 individuals have been prosecuted for practicing FGC (USDOS 2004).

The Code for Persons and the Family (in force since 1990) regulates marital practices. Stipulations of the Code include:

- Legal age of marriage: Only men older than 20 and women older than 17 may marry, but no punishment is stipulated for violation of this law.
- Choice of spouse: Marriage requires the consent of both parties. It specifically prohibits "forced marriages, particularly customary marriages and those imposed by families, which compel the surviving spouse to marry one of the deceased spouse's relatives." The penalty for forcing a person into marriage is imprisonment for six months to two years (Article 376).

- Monogamy is designated as the legal form of marriage, although if prospective spouses mutually consent to a polygamous union and sign a declaration before an official, the practice is permitted.

- Bride-price is prohibited, incurring a sentence of three to six months in prison and/or a fine of 150,000-900,000 CFA francs (US\$239-1433) for offenders (CRR 1999).

- Abandonment of a pregnant woman: Abandonment of a pregnant woman is punishable by law, but only in cases of legal marriage; pregnant adolescents who are abandoned are frequently unmarried and are not protected by this law.

- Female genital cutting: performing FGC is punishable by six months to three years imprisonment in addition to a fine, according to Article 380 of the Code. If the girl's death results from the procedure, the length of imprisonment increases to five to ten years.

- Abortion: Inducing abortion or voluntary termination of pregnancy is illegal, according to Article 88. Article 93 allows therapeutic abortion if the woman's life is at risk or in the case of rape, however.

- Rape: The penal code stipulates punishment for rape as imprisonment for five to ten years; the length of time is doubled if the rapist occupies a position of authority over the victim.

These policies and legislation make an important statement about the government's priorities and acknowledge the gender dimensions of adolescents' needs to a certain extent. However, some programs have been developed but have not yet been implemented, others lack well-thought-out monitoring and evaluation schemes to measure effectiveness, and most do not target specific subgroups of adolescents but apply to a monolithic "youth." As in most developing countries, efforts are hampered by limited resources and lack of infrastructure. 


\section{Girls' participation in conventional youth-} serving initiatives

In Burkina Faso, many youth-serving organizations and groups are involved in social and economic issues, such as the environment, education, cultural development, and extension of health services to underserved populations. Until 1990, few organizations specialized in reproductive health issues. As the urgent need for HIV/AIDS information, prevention, and care increased, many youth organizations and groups were created with the main objectives of sensitizing young people to sexual and reproductive health issues, especially those pertaining to STIs including HIV/AIDS.

Youth organizations in Burkina Faso conduct a wide range of activities, including home visits for one-on-one discussions, sports and entertainment, such as football tournaments, cycling races, and dance parties to mobilize adolescents around themes and engage them in debates, conferences, and radio shows.

Coordination between programs is a priority because so many organizations have bloomed. At the 2000 Forum for African Development (FDA), a national network was envisioned for connecting youth organizations, NGOs, and community-based organizations to collaborate on STIs/HIV/AIDS youth programs in Burkina Faso. In response, the government created Réseau Africain des Jeunes de Lutte contre le Sida (RAJLS) / HIV/AIDS Young African Network.

The main objectives of RAJLS are to promote leadership, provide appropriate information and training on HIV/AIDS issues, and to develop an institutional framework for advocacy. Fostering young people's capacities enables them to become active advocates and resources in the area of HIV/AIDS. The organization is comprised of a national secretariat, one focal point for each of the four regions of Burkina Faso (West, East, Center, and North), and provincial coordinating entities, small organizations, and 117 community-based organizations in 38 of the 45 provinces. RAJLS is supported by governmental agencies including the Ministry of Health, the Ministry of Social Action and National Solidarity, the Ministry of Youth, and the Permanent Secretary of the National Council for HIV/ AIDS, as well as by international and bilateral institutions such as the United Nations Children's Fund (UNICEF), the United Nations Population Fund (UNFPA), the World Health Organization (WHO), the United Nations Development Programme (UNDP), the Joint United Nations Programme on HIV/AIDS (UNAIDS), the Deutsche Gesellschaft für Technische Zusammenarbeit (GTZ), the Japanese Embassy, the Netherlands Embassy, and others.

\section{Responding to the diversity of adolescents}

Perhaps the greatest current challenge in programming for adolescents is to move the field away from overly generalized efforts directed at an ageless, genderless mass variously described as "adolescents," "youth," "teenagers," and "young people" toward the identification of subgroups of particular interest (Bruce and Chong 2006). Much of such programming is designed to help adolescents or young people (with no further specification) achieve generalized goals such as "acquisition of life skills" or "better reproductive health" or the "ability to make better choices." Youth-serving organizations and national programs may represent themselves as serving all young people-simultaneously responsible, in theory, for reaching the unmarried ten-year-old girl at school, the urban schoolboy of 17 , the out-of-school boy of 14 employed in a periurban area, and the married 16year-old girl living in a remote rural area.

Investments in adolescents will have limited yield unless they are more specifically targeted to subsets of adolescents, differentiated by age, sex, marital and schooling status, social status, economic class, living arrangement, and urban-rural residence. A communitymapping exercise conducted by the Population Council (see box) illustrates the diversity of those included in the catchall term "adolescents" and how programs must take into consideration contextual issues in trying to reach the most vulnerable adolescents.

\section{Coverage exercise: Whom do peer educators reach?}

Once the internal diversity of adolescents is recognized and certain subgroups are highlighted as being socially excluded and economically vulnerable, the logical next step is to determine whether these subgroups are being reached by currently configured youth-serving initiatives. Findings from several sub-Saharan countries, including Ethiopia, Ghana, Guinea-Bissau, Kenya, Mauritania, South Africa, and Zimbabwe, suggest that youth centers and peer-education and family-life-education programs typically benefit schoolgoing and/or urban populations disproportionately, favor older boys' participation, and not uncommonly serve high proportions of older males. Rural populations, adolescent girls and boys who are out-of-school or living apart from their parents, and married girls are grossly underserved by or entirely absent from such programs.

Researchers at the Population Council developed the "coverage exercise" methodology, a low-cost, easy-touse data-collection system that enables programs for young people to track which subpopulations they are reaching. For comparison of three countries, see Lardoux 
(forthcoming). To see if the trends found elsewhere also hold true in Burkina Faso, Population Council staff, in collaboration with UNFPA, implemented a coverage exercise in 2005 with 35 peer educators from 20 organizations working with adolescents from rural and urban areas. All nine organizations running peer-education programs with assistance from UNFPA were included; 11 additional organizations from diverse regions in the country were also represented in an attempt to broaden geographic representation. Peer educators noted key demographic information about the people they came into contact with for one month.

During the four weeks of data collection, peer educators reported a total of 6,860 contacts with 6,216 individuals. Nine percent were repeated contacts with an individual. On average, a peer educator made 50 contacts per week.

The organizations chose one or two of their best peer educators to participate in data collection. Twenty-one of the peer educators were men and 14 were women. The median age of the peer educators was 24, and majority of them were single (71 percent). They had served as peer educators for at least five years.

More boys (56 percent) were reached than girls (44 percent). This finding may reflect the fact that a higher proportion of the peer educators were male than female, and that boys were more likely to speak with boys. Only 7 percent of the individuals in contact with a peer educator were aged 10-14 (see Table 9), whereas 63 percent were aged 15-24; as many as 30 percent were older than 25 , and 14 percent were older than 30 . The majority of both sexes had received a secondary education or higher (57 percent of boys and 52 percent of girls). Seventy-one percent were not married.

The results of this study clearly suggest that peereducation programs are reaching those with the greatest advantages. Although one program (see p. 19 “Mèreéducatrices"), was reaching married girls, the majority of young people in contact with the peer educators were single. A recent, nationally representative study conducted in Burkina Faso found, however, that more than one-third of girls aged 15-19 are already married and that 25 percent of this age group have already been pregnant ( $A G I$ 2004). By the age of 17, one in five girls has borne a child or is currently pregnant. These findings suggest that married girls between the ages of 15 and 19 may warrant special programmatic attention, especially in light of the brief interval they experience between first marriage and first birth.

These peer-education programs are also not reaching the youngest age groups for either boys or girls. The programs rely on individuals who may wish to remain

\begin{tabular}{|c|c|c|c|c|c|}
\hline \multicolumn{6}{|c|}{$\begin{array}{l}\text { TABLE } 9 \text { Percentage of young people in contact with } \\
\text { peer educators, by age, education, and marital status, } \\
\text { according to residence and sex, Burkina Faso, Coverage } \\
\text { Exercise, } 2005\end{array}$} \\
\hline \multirow[b]{2}{*}{ Characteristics } & \multicolumn{2}{|c|}{ Urban } & \multicolumn{2}{|c|}{ Rural } & \multirow[b]{2}{*}{$\begin{array}{r}\text { Tota } \\
(n=6,216\end{array}$} \\
\hline & $\begin{array}{r}\text { Boys } \\
(n=2,993)\end{array}$ & $\begin{array}{r}\text { Girls } \\
(n=2,287)\end{array}$ & $\begin{array}{r}\text { Boys } \\
(\mathrm{n}=512)\end{array}$ & $\begin{array}{r}\text { Girls } \\
(n=424)\end{array}$ & \\
\hline \multicolumn{6}{|l|}{ Age (years) } \\
\hline $10-14$ & 8 & 7 & 4 & 2 & 7 \\
\hline $15-19$ & 29 & 37 & 15 & 25 & 30 \\
\hline $20-24$ & 33 & 34 & 28 & 36 & 33 \\
\hline $25-30$ & 18 & 11 & 26 & 22 & 16 \\
\hline $30+$ & 12 & 11 & 27 & 15 & 14 \\
\hline \multicolumn{6}{|l|}{ Educational level } \\
\hline None & 24 & 27 & 35 & 35 & 26 \\
\hline Primary & 17 & 20 & 23 & 18 & 15 \\
\hline Secondary + & 59 & 53 & 42 & 47 & 55 \\
\hline \multicolumn{6}{|l|}{ Marital status } \\
\hline Single/never married & 76 & 67 & 63 & 56 & 71 \\
\hline Engaged & 5 & 8 & 3 & 7 & 6 \\
\hline Married & 17 & 21 & 32 & 29 & 20 \\
\hline Separated & 1 & 2 & 1 & 2 & 1 \\
\hline Divorced & 1 & 1 & 1 & 2 & 1 \\
\hline Widowed & 0 & 1 & 0 & 4 & 1 \\
\hline
\end{tabular}

peer educators for a long time. Using peer educators who have five or more years of experience can be beneficial in that the cost of training is minimized and educators hone their skills over time. Using an aging cadre of peer educators may, however, result in the exclusion of younger educators, because they are likely to remain in contact with their own age cohort. The desire to remain a peer educator for many years may reflect the high unemployment rates in the country. Peer-education programs would benefit from careful delineation of their target subpopulations. Consideration of the peer educators' demographic characteristics is necessary for reaching the most vulnerable groups.

\section{Programs reaching adolescent girls}

As the coverage exercise indicates, without concerted effort, programs directed at "youth" tend to benefit disproportionately people who are older, better educated, urban, unmarried, and male. By no means does this description characterize all programs in Burkina Faso, however. A few programs are discussed below that have been particularly effective or innovative in reaching neglected subgroups of adolescent girls.

\section{Milles Jeunes Filles - The Thousand Young Girls Project}

The Milles Jeunes Filles (MJF) project is an exemplary national effort to provide adolescent girls with skills and knowledge in a supportive environment. The only government program of its kind, it was started in 1994. Since 
then, 2,000 girls have graduated from the program. Also referred to as the Centre de production et de formation pour jeunes filles, the MJF program was initiated by the president of Burkina Faso as part of a larger plan to increase the country's agricultural production. Its initial goal was to teach the most up-to-date agricultural and cultivation techniques to a previously untapped portion of the country's workforce. The program expands young women's roles, provides them with a livelihood, and enables them to make a contribution to the welfare of their families, their communities, and the country as a whole.

The significance of this innovative program lies in the general absence in developing countries of public policy that focuses on the needs and abilities of adolescent girls. As the MJF curriculum was developed, equipment was donated and facilities were built, and activities expanded in scope beyond agriculture to create a far broader program. Once all these components were in place, the complete program included training in the areas of:

- literacy

- reproductive health

- hygiene

- raising livestock

- dressmaking
- agriculture

- environmental studies

- money management

- sports

- cultural activities (music, theater)

Several organizations collaborated to develop this program, including the Ministry of Family and Social Welfare, the Ministry of Health, UNFPA, and the Population Council. The Council was involved with development of the reproductive health component, conducting baseline and endline surveys with program participants and increasing the program's support for graduates.

The MJF project recruited 14-18-year-old girls from all regions of Burkina Faso, primarily from rural areas. The program sought out-of-school adolescents but accepted some girls who were in school or had some education. Initially, parents refused the invitation to send their daughters away for training, deeming it unnecessary, particularly since the girls were sometimes already engaged and the training provided by the program would delay their weddings. Program coordinators eventually convinced parents that the training provided by the program would be beneficial and would enhance rather than hinder their daughters' marriageability. Ultimately, many parents agreed to enroll their daughters, and over time parents began to request that their daughters be accepted into the program.

The participants live at two centers in Sourou during the two-year program. The first group of 1,000 girls (known as the first promotion) was in residence from
I was in grade 8 when my brother died. He bad been paying my school fees, so I was obliged to drop out of school. I returned to the village and belped my mother. I was in a situation I did not wish for. The village delegate came to visit my parents to ask if they wanted their daughter to participate in a training in Sourou. I was truly bappy to get another opportunity to learn new things.

— MAMOUNATA SOULGA, SECOND PROMOTION

1994-96. Instruction and skills training are conducted both in French and in the local language of Gourmantché. In the first year of training, girls learn basic skills for a variety of trades. The second year allows them to specialize, selecting a single occupation that they plan to practice after completing the program.

Once the girls of the first promotion returned home and the community witnessed the program's results, community and parental support grew and resulted in increased demand. To allow for more individual attention and improve the program's quality, subsequent promotions were reduced in size; 500 girls were admitted for both the second and third promotions. The second promotion was trained from 1996-98. The program's third promotion graduated in 2003.

The Population Council's evaluation of the program informed changes to the curriculum and supported continuous quality improvement. For example, during the first promotion, girls learned to grow tomatoes and cabbages. In the second promotion, training expanded in response to feedback to include planting of eight crops, and participants learned how to preserve their produce in jars. After leaving the program, some girls found that selling vegetables in jars enabled them to save and sell more of their crop, a more profitable business than selling only fresh produce.

In addition to gaining profitable skills, the girls acquire general knowledge about many topics including health, the environment, and finances. The girls learn about their reproductive health and rights, how to care for children, and how to communicate and negotiate within their relationships. Discussions about genital cutting motivate the girls to question traditional practices. MJF seeks to increase girls' sense of self-worth so that they are enabled to make decisions for themselves. Upon completion of the program, the MJF graduates were eager to return home and spread their knowledge to their sisters and to other women in their communities. 
Supporting girls after they have completed the program is essential, because the goal of MJF is to enable girls to be productive and engaged members of their communities. The Population Council developed a system of support for program graduates that allowed them to make use of their skills. For example, each participant received a grant for purchasing supplies so that she could begin working independently. Upon returning home, program graduates were placed in contact with local female mentors. Using the grants from the program and outside grants and loans, they began working, saving, and reinvesting their money in their chosen occupations. Local government agencies offered land for planting and gave the girls more land as they proved themselves to be highly productive. Interviews with the graduates indicate that the MJF program's approach has profited the girls and their families:

The whole family benefitted from ber training. She advises people; she bas sent her younger sisters and brothers to school because I don't have the means. She has gathered the girls in the neighbourbood to teach them ber skills. - FATHER OF SAFI ROMBA, FIRST PROMOTION

I wanted to share my knowledge with the others. So I gathered the girls (some are literate, some are not), and we started meeting and working together. Our group is two years old now. My association is called "Girls of the Future."

\section{— SAFI ROMBA, FIRST PROMOTION}

Girls expressed pride in their new skills, as did their families. The girls volunteer their skills, educating women locally. They were given educational materials, including visual aids, and bicycles so that they could travel to give lectures on health, magnifying the impact of the program. By serving as leaders, the girls gained their communities' respect.

The Population Council conducted exit interviews with the first-promotion girls after they returned home. Baseline and exit interviews were conducted with the second-promotion group that revealed dramatic changes in their knowledge and attitudes. Before entering the program, the girls did not feel empowered to make decisions; even their participation in Milles Jeunes Filles was a parental decision. Many girls did not know about the program until after the decision to enroll them had been
I was asked to work with the agents of the [health] dispensary. When they go to the villages for immunization, I provide community education while the nurses vaccinate children. At the beginning I bad difficulties ... they asked me questions I could not answer. So the nurses who were nearby belped me answer the questions. When the [MJF] project organized a further training course, I was able to improve my knowledge.

- MAMOUNATA SOULGA, SECOND PROMOTION

made. After completing the program, however, the girls were prepared to make their own choices. For example, some girls were able to delay their marriages, and when they married, they selected their own husbands.

The Mille Jeunes Filles graduates have taken on roles in their families and communities that would have been unimaginable for them at the start of the program. Interviews revealed that the participants have formed a dynamic network of young women who are capable of working collectively to bring change to their communities. Continued observation of MJF graduates will reveal the program's long-term impact; however, MJF has already shown that investing in adolescent girls yields significant positive results.

\section{Training "mère-éducatrices" to reacb married adolescent girls}

In the absence of programs designed to reach married adolescent girls, the Council implemented an intervention that sought to reach these girls in their homes. Formative research on the lives of adolescents highlighted the heightened vulnerability of married girls and provided evidence that standard reproductive health interventions for adolescents would not be appropriate, relevant, or feasible for this group. Married adolescent girls have limited mobility; therefore, their participation in community life is severely constrained. Activities for married adolescents must be situated within their homes and family spaces, at least initially, rather than in public spaces.

To reach married adolescents in their homes, the project team decided to train young mothers from the community to visit girls and provide support during their first pregnancy and childbirth. The mothers would form a cadre of resource people, referred to as mères-éducatrices (mother-educators). The mères-éducatrices would 
also educate relatives and others (husbands, mothers-inlaw) who have influence over married adolescent girls.

The intervention's primary objective was to test the feasibility of using mères-éducatrices to provide information to married adolescent girls. Additional objectives included identifying meeting venues, determining appropriate content (skills-building, savings mechanisms, reproductive health), and developing indicators for the evaluation of project outcomes.

The intervention for married adolescent girls was developed in four rural sites where the marriage studies had been conducted: two locations in Gourma (Natiaboani and Koaré) and two in Bazega (Gaongo and Nafbanka). The project team recognized that community support was essential, so they allotted time for community mobilization. The mobilization strategy involved gathering ideas and seeking input from local village assemblies, community leaders, and the general public to inform the design of intervention activities and objectives.

The project team began by developing criteria for the mères-éducatrices; they had to be aged 19-24, married with at least one child, and be selected by their community. Subsequently, 30 young women meeting these criteria were identified by the communities for training.

The training curriculum was developed in collaboration with the Ministry of Health, UNFPA, and the Ministry of Social Action. The curriculum covered basic reproductive health, with a heavy emphasis on prenatal care. Given the difficulty in separating married young women from their household duties for an extended period of time, training activities were broken into three short sessions of one week each, with a period of two weeks between each session. During the two-week break period between sessions, the educators returned to their communities and began the sensitization efforts. During this stage of community mobilization, it was clear that family members close to the young women (particularly husbands) must be actively included in the sharing of pregnancyrelated information and support. Sensitizing husbands so that they would cooperate with the mères-éducatrices was important for the success of the program.

After the training, the four target locations were divided into areas, with a pair of mères-éducatrices assigned to each area. The mères-éducatrices identified recently married adolescents and pregnant married adolescents in their assigned area. The 30 mère-éducatrices traveled in pairs, conducting visits with the married adolescents in their homes. They provided them with information, answered their questions, distributed Vitamin A and iron supplements, and spoke with the gatekeepers in the household to ensure their cooperation.
Over time the educators were able to help program participants gain greater mobility so that, eventually, they could participate in activities outside their homes. Their goal was to enable the married girls to gather with their peers and also to travel to the health center. In order to increase the proportion of deliveries attended by a trained health worker (only 31 percent of births to adolescent mothers are attended), mères-éducatrices act as liaisons between married adolescents and local health centers. In addition to escorting girls to the centers for prenatal visits and educational sessions, the mères-éducatrices also helped sensitize health workers to the particular needs and vulnerabilities of young married girls. By acting as community liaisons and bringing women to the health centers, the mères-éducatrices garnered the support of the Ministry of Health's agents and strengthened their own position within the community.

The mères-éducatrices also provided services to the general community. They showed educational films and led discussions, with support from agents of the Ministry of Health. They were equipped with a basic health kit which included iron tablets, Vitamin A, and condoms to distribute to community members as appropriate.

These efforts represent the start of a promising program. Through this intervention, the feasibility of gathering married adolescents together to exchange information and ideas and to create a peer network and mentoring support, is being explored. These elements of the program will serve to decrease married adolescents' social isolation, increase their social standing, and allow them to exchange information safely and effectively about sensitive reproductive health and life-skills issues. Future activities may include functional literacy training and forming savings clubs.

The mères-éducatrices have proved to be well respected and appreciated, and are viewed as offering a highly valued service to young married adolescents and to the community more broadly. The sustainability of this approach will depend on the motivation of the mères-éducatrices and on continued community support.

\section{Promoting girls' education through a food-assistance program}

Educational enrollment is low for all adolescents in Burkina Faso, particularly for girls and those living in rural areas. Fewer than one of three girls aged 10-14 are in school, and only 7 percent of rural girls complete primary school (INSD and ORC Macro 2004). Children may be kept home from school because help is needed with household work or the care of younger children, or because the family may not be able to afford the cost 
of books, uniforms, and school fees. To address this situation, Catholic Relief Services (CRS) in partnership with the Ministry of Basic Education and Literacy began the Girls Education Project in 1997 as a pilot program in three provinces, reaching 100 girls. The program has grown over the past decade to include 107 primary schools and more than 7,000 girls and their families across eight provinces.

The program has three primary objectives:

- to increase educational access among rural children whose food supply is insecure;

- to increase girls' enrollment in and attendance at targeted primary schools; and

- to increase parental awareness of, involvement in, and support for primary-school education for boys and girls.

The Girls Education Project seeks to achieve these goals by several means. The Take-Home Ration (THR) program rewards primary-school girls with attendance rates of 90 percent or better with a monthly food ration of 10 kilograms of cornmeal (about 22 pounds). The preschool food-assistance program is designed to encourage parents to send their youngest children to preschool (where they are provided with lunch), so that their older sisters are freed to attend school. Health, hygiene, and nutrition (HHN) activities, including delivery of Vitamin A supplements and deworming medication to targeted primary-school students, are undertaken to improve children's health, nutritional, and psychosocial status. In addition, a food-for-work school-infrastructure-improvement initiative (in partnership with UNICEF and the Ministry for Social Action and National Solidarity) builds and improves classrooms and teachers' quarters, and provides water and sanitation infrastructure. Lastly, an information, education, and communication campaign was mounted to raise community members' awareness of the importance of girls' school attendance, of the HHN needs of children and adults, and of community involvement in education. CRS developed drawings, bulletin boards, and guides, and in some communities it collaborated with local theater companies to spread these messages.

CRS has achieved notable success with its Girls Education Project. In 2005, 7,892 girls' attendance rates qualified them to receive take-home rations, and 2,171 children in 25 preschools benefitted from food assistance. Dropout rates for girls attending schools participating in the THR program decreased to 3.8 percent, almost 50 percent lower than the dropout rate for girls in other schools. Moreover, 82 percent of older sisters of preschoolers enrolled in the food-assistance program were able to attend primary school.
The program has had an impact on not only girls' lives but also on their families' lives. A transformation has occurred in the attitudes of parents and community members regarding girls' abilities and what they can achieve. In the early years of the program, many people in the community felt that the principal benefit of sending girls to school was the food ration that they brought home every month. Over time, families noticed that their daughters were more intellectually curious and knowledgeable, and they valued the girls' new skills in performance of everyday tasks, such as reading labels on medicine bottles or checking the addition on bills. Parents also appreciated the implications that their daughters' education had on their future earning potential and on the wider range of livelihood options available to them. The increased esteem accorded to girls, in combination with reduced insecurity concerning the food supply, has had the far-reaching effect of reducing the prevalence of early marriage. The project's accomplishments have been recognized and lauded by other organizations: The Forum for African Women Educationalists presented an award to CRS for the positive effects its project has had on girls' education, and the World Food Program is seeking to replicate this project in four additional provinces in Burkina Faso.

\section{Combating the trafficking of children}

Trafficking is a significant problem in Burkina Faso because the country is a source, transit route, and destination for the selling of children and adolescents. An estimated 165,000 Burkinabés are trafficked for forced labor and sexual exploitation within Burkina Faso as well as to Benin, Côte d'Ivoire, Ghana, Mali, Niger, Nigeria, and Togo. In addition, Malian and Nigerian children are frequently transported into Burkina Faso. Victims of trafficking are subject to inhumane conditions in domestic work, the informal sector, metal work, and agriculture. About half of trafficked children are girls, and slightly more than half were trafficked by their families.

UNICEF's Protection project seeks to reduce trafficking in Burkina Faso through awareness campaigns and the interception of trafficked children. The project includes an attempt to improve the working conditions of trafficked children, to encourage out-of-school adolescents to enroll in formal schooling, and to provide services to the recovered children and their mothers where possible.

UNICEF undertook research to assess the trafficking situation in Burkina Faso, identified common internal trafficking routes, and alerted local authorities to take action. The agency established five centers that served 644 children in 2003 . The program follows the recovered children through their reintegration into their families. 
UNICEF worked with government agencies for the repatriation of children from other countries. Working with mothers was an important innovation of the project, because mothers have been found instrumental in pushing their daughters into exploitative employment. By offering mothers microcredit, training in income-generating activities, and counseling and education concerning the dangers of trafficking, the program improved the situation of children who were returned to their families.

The project staff held sensitization activities to draw attention to the issue and to the laws that exist to protect children. These events included talks or films with discussion periods reaching approximately 10,000 people.

Additional activities were held to educate girls employed as domestic workers, offering literacy classes and apprenticeships while they continued their domestic work. This project reached 101 girls. The majority were not being paid for their labor. Seventy percent were younger than 15 , and 45 percent reported that they began working between the ages of six and 12. Girls employed in domestic work reported many problems; 58 percent indicated that they had experienced one or more of the following: verbal or physical abuse, fatigue, food deprivation, and no contact with their families. Classes were held from 1:00- 3:00 p.m., five days each week, and included literacy training in Moore or French, knitting and dressmaking, reproductive health and hygiene, and negotiation skills to enable them to speak with their employers about improving their living situations.

At the program's conclusion, ten of the girls left domestic work and were able to enter primary school. Nineteen girls were enrolled in evening courses for professional dressmaking. Thirty-two girls received bicycles to enable them to go from their place of employment to an apprenticeship. Twenty-seven girls learned to preserve fruit and vegetables, dye cloth, and make soap. At the end of the classes, none of the girls reported an unwanted pregnancy. The girls remarked that the intervention improved their relationships with their employers and helped them to develop plans for the future.

UNICEF is continuing to call for stricter enforcement of existing laws to protect girls in Burkina Faso. Moving forward, they are developing cooperative protocols with bordering countries, particularly with Côte d'Ivoire. 


\section{ADOLESCENT GIRLS IN BURKINA FASO: A FORWARD-LOOKING AGENDA}

A dolescence is beginning to emerge as a protected and explicit stage in the life cycle-a space between childhood and adulthood-for young people in Burkina Faso. Although adolescence (to age 18) is legally part of childhood, it is often defined culturally as early adulthood. Burkina Faso's constitution confers substantial rights and possibilities on both men and women beginning at age 18 .

Policy concerning adolescents must be conceptualized as part of a life cycle of policies that take effect at infancy; such policies must be framed to lay a foundation for a safe transition to adulthood, taking into account the enormous internal diversity of Burkinabé youth, and the important disparities in life experiences and opportunities for adolescents by age, sex, residential status, schooling, marital status, and location. A single policy for the young will not serve adolescents any more effectively than a single adult policy would serve adults. Burkinabé adolescent girls are by no means an homogenous group. Rural adolescent girls are at a particular disadvantage as a result of their sex, age, relative poverty, and heightened risk of an early and marriage not of their own choosing. Although on the decline, harmful traditional practices such as female genital cutting and polygamy persist throughout Burkina Faso, losing their hold less rapidly in rural areas, particularly in the north. The process of marriage, particularly child marriage, requires special policy attention. The current culturally condoned marital process is at best disenfranchisement, and at worst a human rights abuse. Yet it is a deeply embedded part of Burkinabé culture, and most girls and women look forward to a time when they are in loving partnerships and have children. A key implication of early marriage is that policies must take into account the dramatic change in girls' situation at the time of puberty, when their families' concerns about their marriageability rise. Policies must be implemented that produce regulations and supports concerning marriage in terms of mutual consent, timing, selection of partners, and the role of economic exchanges. For many women the key decision in their life-social, economic, and in terms of identity and health - is the marriage decision, and often it is not their own decision.
Apart from individual health, rights, and economic arguments, investments in rural adolescent girls is plausibly the most strategic way for Burkina to achieve the Millennium Development Goals, because these types of investments can:

- alleviate poverty;

- increase access to education;

- foster equality and empowerment for girls and women;

- reduce maternal mortality and related child mortality;

- contain the transmission of infectious diseases, especially HIV; and

- reduce rapid population growth, achieving a better balance of population and resources.

Strategic investments in adolescent girls is the key to achieving all of these goals. For many girls and their families poverty is guaranteed in the decision to withdraw girls from school and marry them off early. The youngest first-time mothers bear the brunt of maternal mortality and closely related infant mortality. Increasingly, the youngest girls, married and unmarried, are being afflicted with HIV - as a consequence of their sex, their junior social status, and their lack of economic bargaining power. The education of girls and the timing of marriage and first birth are closely related to the rates of population growth; a high proportion of future population growth in Burkina Faso will come from population momentum - the tendency of populations to keep growing even when people's ideal family size begins to decrease (as is the case in Burkina Faso). Unless the age at marriage and first birth are adjusted upward, the demographic dividend-a rising proportion of working-age adults in relation to children and older populations-cannot be achieved or seized. Extending girls' time in school and delaying their sexual initiation until at least age 18 result in substantial returns at both the individual and aggregate level.

Thus, many interlocking factors point to the importance of making investments in adolescent girls a priority. In the life-cycle approach described below, we 
suggest steps that are simultaneously beneficial (many of which can and should be extended to boys), that will improve the quality of life for girls and their families, and that will assist Burkina Faso to progress toward the achievement of the Millennium Development Goals, fulfilling the promise of the Burkinabé Constitution, and affirming the international agreements to which it is party.

\section{Infants and young children: A healthy, documented beginning to girls' lives}

\section{Actions}

- Institute a process through which mothers who give birth at home can easily register their children's births.

- Improve young married women's access to national identity cards for those who do not have them.

- Link efforts to prevent infant female circumcision to married adolescent outreach initiatives.

- Document the existence of rites of passage that can replace female genital cutting.

- Test models of these other rites of passage.

- Link basic education programs to reproductive health information, including the harmful consequences of female genital cutting.

\section{Birth registration and identity cards}

Promoting a girls' sense of self during adolescence can begin at birth with the provision of national identity cards. Currently, programs run by agencies such as UNICEF, Plan Burkina Faso, and the Ministry of Social Action work to ensure that birth certificates are issued to newborn children and that they receive national identity cards. Yet generally only children born at health centers are officially documented; women who deliver at home-the majority in Burkina Faso-must make special efforts to register their children's births and may face difficulties in doing so. Those who must obtain permission from a husband or other family member to travel to register a birth may not receive it or may lack the funds for transport. Anecdotal evidence suggests that many mothers are, themselves, not registered and that husbands fear that if their wives obtain identity cards, too, their behavior may change. Many new parents may not appreciate the necessity, later in life, of their child's having an official birth certificate. On a purely practical level, bureaucratic processes are less cumbersome to those with such documentation; the benefit of having an official identity in the eyes of the state and the world is both intangible and invaluable.
Because the majority of Burkinabé births are still largely unregistered, an excellent opportunity exists to work for change in this area. The program that uses mères-educatrices, described above, is one example of a program that focuses attention on first-time mothers in Burkina Faso. Although these adolescent girls and young women are encouraged to deliver their babies at health centers, for many such a course of action remains impossible. This program could help create a liaison between the new mother and the Ministry of Territorial Administration and Decentralization to increase the number of home births that are registered promptly.

Preventing female genital cutting from infancy onward

With increasing awareness among adolescent girls about the dangers of female genital cutting, girls are beginning to refuse to undergo the procedure, much to the dismay of family elders. One unintended consequence of their refusals is earlier circumcision. Instead of waiting until a girl has reached puberty to perform circumcision as a rite of passage to adulthood, some communities are circumcising infant girls to avoid risking their refusal when they are older. Although the current generation of adolescent girls who are not yet mothers may refuse to be circumcised and have no plans to circumcise their daughters, their slightly older sisters who are already married (and already circumcised) could be targeted for preventing circumcision among their infant daughters. Such an initiative could be linked with outreach programs for first-time parents.

Another approach that merits further investigation is the introduction of alternative rites of passage to adulthood in communities that circumcise their daughters. Such an initiative goes a step beyond changing community norms, because it recognizes the cultural importance of a rite of passage while promoting an alternative that maintains girls' bodily integrity. Examples of such efforts exist in Kenya, where Maendeleo Ya Wnawake (MYWO), the Program for Appropriate Technology in Health (PATH), and the Population Council implemented a systematic assessment of anti-FGC efforts in three districts in Kenya starting in 1996 (Chege et al. 2001). The study focused on the Alternative Rite of Passage program made up of three interrelated components: community sensitization, seclusion and training, and public ceremony. Community-sensitization activities provided information about the health risks of FGC and fostered awareness that the practice violates girls' human rights. The seclusion and training portion of the program was meant to mimic the traditional practice whereby girls are secluded immediately after circumcision and are taught 
about women's roles, cultural values, and sexuality. The exact nature of the public ceremony was dictated by the specific sociocultural context of the community. The program had varying levels of success by district, ethnic group, and religious background. Girls that participated in the alternative rites exhibited greater knowledge and awareness of reproductive health issues and slightly more positive gender-equality attitudes than girls who did not. For the approach to be replicated successfully in other settings such as Burkina Faso, thorough understanding of the role of public (as opposed to familial) ceremonies in that culture will be required, as well as a carefully considered judgment as to what ritual format is the most appropriate for helping those who have decided to abandon the practice of FGC. The assessment indicates that sensitization activities should proceed or accompany the introduction of an alternative rite in order for a change in attitude to occur.

Finally, a broad approach to community involvement and women's education also warrants attention, as shown by the Tostan program (Tostan 1999). Starting in the late 1970s, a basic education program was developed by a nongovernmental organization in Senegal called Tostan. It was designed to improve the educational and socioeconomic situation of rural women and children. Tostan consisted of six basic modules focusing on reading, writing, arithmetic, and life skills, and proved to be extremely successful in teaching women technical and practical skills and providing them with the opportunities to use and retain their new knowledge. The Tostan program offered thousands of Senegalese women information and strategies for social transformation, as well as means of developing their confidence and self-determination. In particular, the Tostan program allowed women the opportunity to learn about the health risks associated with FGC and, more importantly, the forum and newfound confidence to speak about their experiences and sufferings. Following the brave and historical declaration of the Malicounda Bambara village in 1997, tens of other villages officially declared an end to the practice of female circumcision. Through plays, discussions, explanations from religious leaders, and the sharing of personally experiences, the dialogue and debate gained momentum. In 1999, after discussion with a delegation from the villages that had already ended the practice, a law was passed by the Senegalese Parliament to abolish the tradition of female circumcision. The far-reaching accomplishments of the Malicounda women and the many women who followed their lead, would never have been possible had they not received basic education in skills for living provided by the program.
Schooling: Helping girls arrive at school on time and keeping them there

\section{Actions}

- Build community commitment to girls' education.

- Document the girl-friendliness of the school environment.

- Examine possibilities for policy change that enables girls to enroll late or return to primary school should they need to withdraw for any reason.

- Develop alternative education models for the youngest girls who are not in school and reinsertion programs to return them to school.

- Evaluate current efforts to integrate life-skills education into primary-school curricula.

The Tostan experience highlights the benefit of investing in girls' and women's education. Increasing girls' schooling is of the utmost importance for achieving the Millennium Development Goals, both in terms of reaching the goal of universal primary education and improving gender equality of within schools. A recent report analyzing Demographic and Health Survey data from 50 countries shows a strong association between schooling and reproductive health outcomes (Lloyd 2004). For example, unmarried 15-17-year-old girls in school are less likely than their out-of-school counterparts to report sexual debut. Those who are in school, in addition to receiving formal education, also enjoy the social networks and protection that come from interacting regularly with their peers and with nonfamilial adults. Furthermore, recent analysis of DHS data from sub-Saharan Africa, including Burkina Faso, suggests that girls of 12 who are not in school at the correct grade for their age are more likely to drop out of school, marry early, and bear a child soon after they marry (Lloyd and Mensch 2006).

Currently, a number of experimental programs that aim to keep girls in school are operating in Burkina Faso's rural communities. One such program is operated by UNICEF and involves giving bicycles to girls for whom the distance to the nearest school is an impediment to their attendance. When a girl finishes primary school successfully, the bicycle is hers to keep. Such a program merits careful documentation and evaluation. Little is currently known about the school environment in Burkina Faso. Mensch and Lloyd (1998) describe a situation in Kenya in which primary schools are hostile environments for girls. Teachers are abusive, and both teachers and male students harass girls. Research is needed in Burkina Faso to discover if schools are places where girls want to be, where they feel safe, and where they can learn. 
Because many Burkinabé girls will attend primary school only, the government has mandated that lifeskills education be integrated into the curriculum. Some of the topics in this area include legal rights, including the laws regarding marriage (and age at marriage), a sensitization to gender issues and women's status, and health education. Monitoring and evaluation are needed on a school-by-school basis to determine how well integrated these lessons are into the overall curriculum.

The current policy stipulates that girls who are not enrolled in school by the time they are seven are not permitted to enroll, a deprivation that is compounded when a girl lacks a birth certificate to prove her age. Policies regarding school reentry for those who left are similarly strict. Alternatives to these current policies should be investigated and a framework for change drafted. Alternative education for the youngest girls - those aged 5-9-who are not in school should be explored. Options for long-distance learning should be considered and support for sibling tutoring in instances where an older sibling or cousin or village friend has had the opportunity to attend school. The Ministry of Education is best placed to undertake this kind of exploration.

A number of other countries have pioneered oneroom and specially adapted schooling approaches to include rural girls who have either never been or are not currently in school. The Ishraq program in Egypt is an example of a successful program that provides an opportunity for girls aged 11-15 who are currently not in school; they participate four times a week in a functional literacy program combined with life skills and sports (Brady et al. 2006). Ninety-two percent of the graduates passed the schooling exam and are eligible to enroll in secondary schools. (A problem in Egypt, as elsewhere, is the lack of suitable secondary schools for these girls to attend.) The Bangladesh Rural Advancement Committee (BRAC) has pioneered what is perhaps the best internationally known catch-up education program with its special community-based schools where 70 percent of students are girls. More than one million students, aged 10-14 attend class for three hours per day during the periods of the agricultural season other than planting and harvest times, so that their schooling is organized around their agrarian activities. Similarly, graduates from these schools are able to continue their education in a secondary school and pass exams, often at a parallel or higher rate than those who have been formally educated since childhood. A number of models exist for catch-up education programs that are appropriate for the needs in rural areas of Burkina Faso-models that reflect girls' relatively poorer access to education but that include both sexes.
Support, protection, and legal redress for girls in extreme circumstances

\section{Actions}

- Conduct qualitative research to understand girls' experience of rural-urban migration in Burkina Faso, including the relationship of the migration to girls' marriage plans.

- Calculate an estimate of the number of young female domestic workers in the largest cities.

- Conduct qualitative research with domestic workers to document their workloads, their treatment by employers, their personal age-wage security, and their needs in terms of health care, access to savings, and social networks.

- Develop program approaches that offer domestic workers life skills, literacy training, health information and access to health services, savings programs, and the benefit of social networks.

- Advocate to enable sex-worker-outreach programs to include sex workers younger than 14 .

- Advocate enforcement of existing laws that were enacted to discourage men from having sex with minors.

- Investigate the benefit of implementing a curfew for adolescents and children in urban areas.

Rural-to-urban migration of young girls is a widespread phenomenon in Africa; typically, a high proportion of African girls aged 10-14 are living apart from their parents. The migration routes that girls use to travel from rural to urban areas should be given special attention; buses and bus stations are particular areas of risk for girls. Whether they flee an unsafe or unwanted situation in rural areas or are heading toward a city full of expectations, they may encounter disreputable people-pimps and others-who seek to exploit girls who are traveling by themselves.

\section{Domestic workers}

Many girls who migrate to urban areas become domestic workers. Currently, little is known about the number and circumstances of these girls in Burkina Faso. A study in two of the poorest neighborhoods of Addis Ababa, Ethiopia, found, however, that the majority of 10-14-year-old girls living apart from their parents (60 percent) were domestic workers, many of whom were living in dire conditions of economic, physical, and emotional abuse (Erulkar 2002). In many cases, these girls were virtual household slaves. They had no safe place to gather or meet friends 
and faced high levels of harassment and the strong possibility of being raped in the public spaces available. At the same time, youth-serving programs failed them completely-less than one percent of contacts of all youthserving organizations were with such girls.

Actually finding a household, even a poor one, in Ouagadougou that does not employ at least one domestic worker is nearly impossible, so estimating how many young female domestics are working in Burkina Faso's cities is difficult. Girls' experiences as domestics are also undocumented. Enumerating them is necessary so that this population of adolescent girls does not remain hidden and unsupported. Qualitative research designed to understand their motivations for and experience of migration and their lives as domestic workers would aid the design of programs to support them by means of social networks, savings schemes, access to health information, and life-skills training, including literacy. Currently, in Ouagadougou, only a single program, Centre de formation des filles aides ménagères, initiated by the Ministry of Social Action, is available to these girls. This program offers cooking, hygiene, and house-maintenance training courses. Clearly, additional programs are needed.

\section{Girls' exchange of sex for gifts, money, or shelter}

The number of young women in Burkina Faso who are forced to support themselves through the exchange of sex for gifts, money, and shelter is also unknown. The Population Council conducted research funded by the PAPMLS/World Bank indicating that 27 percent of Burkinabé women who exchange sex for economic reasons are adolescent girls (15-19 years old). The prevalence of HIV in this population is estimated to be 60 percent, compared with a national prevalence of 4 percent. Currently, however, national policies prevent programs that offer services to sex workers from including those younger than 14. Because paid employment of any kind is illegal under Burkinabé law for those younger than 14, offering health and other services to sex workers aged 11-13 is viewed as an endorsement of underage work rather than as a life-saving strategy for protecting this especially vulnerable population of impoverished adolescent girls. Efforts are needed to lobby for policy change.

At the same time, better enforcement of the law that prohibits men from engaging in sexual intercourse with minors is necessary. Although this law cannot specify the largest group of men who have sex with adolescent girls, namely their husbands, upholding existing stat- utes designed to prevent sexual congress between older males and minor females would effect some protection for young girls.

Another policy strategy that might be helpful is the implementation of curfews for children and adolescents in urban areas. Such a strategy would require that the youngest sex workers would have a safe alternative place to be after dark and an alternative source of income, but for those forced by parents or pimps to do such work, a curfew law might provide some protection for the youngest would-be sex workers.

Ultimately, protecting young sex workers requires political will that does not yet exist in Burkina Faso. Prevention is crucial, but in the absence of viable alternatives, vulnerable girls are too often compelled to engage in sex work.

\section{Street children}

Typically, two categories of street children are found in urban areas of Burkina Faso. The first includes those who live within a family structure (although not always in permanent or semipermanent housing) and who spend their days on the street but have someplace to return to in the evenings. During the day, they may perform unreliable informal wage labor, such as selling telephone cards or oranges, cleaning windshields at stoplights, or any odd job that might be available on a given day. Many of them congregate in groups and may also engage in petty theft or drug use. The second group are those children who have no family in their town or city. They lack shelter, and their social networks comprise only what they are able to piece together on the street. They are entirely responsible for their own well-being and sometimes for that of their siblings. Their survival strategies are varied and, particularly for girls, include sex work. Indeed, although all children and adolescents on the street are vulnerable in myriad ways, girls are especially vulnerable to the risk of sexual exploitation and its consequences, including unwanted pregnancy, infection, fear, and a diminished sense of self.

A small number of organizations operating in Burkina Faso offer outreach to street children, including Médecins du monde, and Terre des hommes Genève. Notably, more efforts to reach street children exist than exist to reach domestic workers, although many members of the latter group may be on the verge of joining the former. Nevertheless, not enough services are available to accommodate the needs of Burkinabé street children. 
Creating a socially supportive environment for girls in rural areas

\section{Actions}

- Experiment with new livelihood-training approaches for girls in rural areas.

- Find employment opportunities for girls from rural areas who have achieved high levels of education, helping them to become leaders.

- Create safe spaces such as girls' clubs.

Evidence is growing that social capital, an individual's access to a network of other individuals and their skills, knowledge, and emotional support, has a strong impact on an individual's health status. Girls in rural Burkina Faso need safe places where they can meet in order to avoid social isolation. Additionally, girls who have managed to graduate from secondary school, despite formidable obstacles, need employment opportunities in rural areas to enable them to be regarded as leaders in their communities. Those who attain leadership status may be able to convince young people in the next generations of the importance of education, and enable them to give something back to their communities. Programs such as the Milles Jeunes Filles should be encouraged to continue to work to find leadership roles for their graduates in their respective communities and to explore new livelihood-training approaches for girls in rural areas.

Delaying marriage until I8, making the transition to marriage safer, and supporting married girls

\section{Actions}

- Enlist support from community leaders in garnering social and cultural will at the national, community, and family levels to enforce existing laws respecting girls' human rights, including their legal right not to be married before the age of 17 .

- Improve unmarried adolescent girls' opportunities to remain in school.

- Increase unmarried, out-of-school adolescent girls' opportunities for economic development.

Child marriage explicitly violates the internationally recognized rights of the child as defined in the United Nations' Convention on the Rights of the Child (CRC). This harmful traditional practice also violates Burkina Faso's own national civil laws that set the legal age of marriage at 17 years for girls and 20 years for boys.
Burkina Faso's political leadership has ratified several conventions and texts to protect women' and girls' rights, such as the $\mathrm{CRC}$, the Convention to End Discrimination Against Women (CEDAW), and the national Personal and Family Code, a progressive set of laws passed in 1989 that describe all rights and laws related to marriage and inheritance, including the legal age at marriage. Nevertheless, as a result of weak enforcement mechanisms and resistance to cultural change, the custom of child marriage persists.

Early marriage is associated with girls' limited education, access to health services, and civic participation. Indeed, only 28 percent of Burkinabé girls aged 7-12 attend primary school, and they drop out of school at a higher rate than boys do. Only 8 percent of girls aged 15-19 remain in school. As a result, the national adult literacy rate for women is only 16 percent, compared with 32 percent for men (INSD and ORC Macro 2004).

The process leading to marriage in Burkina Faso is complex and varies among ethnic groups, communities, and families. Traditional practices perpetuate the violation of the law concerning age at marriage for girls. A variety of strategies is needed to effect change in this process. Increasing community effort to enforce national policies is one way to begin to change norms concerning the age at marriage and spousal age difference. UNICEF and Mwangaza, a US-based NGO, have experience with community-change initiatives to mitigate $\mathrm{FGC}$ and to increase awareness of children's rights. Models of community change, and key lessons learned about shifting norms, could be applied to wide-scale efforts to raise the age of marriage in Burkina Faso.

An effort to strengthen girls' social networks at the community level could prove equally effective. Fostering peer support of girls who wish to delay their marriage is one step; another would be to create linkages between girls' peer groups and community leaders as part of a community-based effort to enforce the legal age of marriage. The Tostan experiment in neighboring Senegal, described on page 25 , is particularly relevant. The single most powerful force in delaying marriage is ensuring that girls arrive at school on time and making it possible for them to stay in school.

The cross-pressures for early marriage that arise from poverty and the perception that marriage is a safety zone are important factors. In many countries, parents may understand that keeping girls in school and delaying marriage may be better for their daughters, but they are concerned about the rising costs of marriage. The relationship between economic pressure and 
marriage must be understood and addressed directly. In the context of the HIV pandemic, parents may believe that marrying daughters increases their safety. Recent research indicates that girls who are married when they are younger than 18 (which qualifies as child marriage) experience an elevated risk of acquiring HIV, because marriage usually propels them from sexual inactivity into frequent unprotected sexual relations (Clark et al. 2006). This point is crucial for parents to understand.

Finally, while the development of programs and policies to delay marriage continues, efforts to support currently married girls is urgently needed. Although married adolescents comprise a large portion of the sexually active adolescent girls in many developing countries, they have received little programmatic attention. Married adolescent girls are not considered either within adolescent sexual and reproductive health field, nor within the context of reproductive health programs for adult women. The distinctive and sharply disadvantaged situation of married girls in Burkina Faso must be addressed through creative and bold new initiatives.

\section{Conclusion}

Although a number of innovative programs have been established to meet their needs, adolescent Burkinabé girls remain vulnerable to many threats to their wellbeing. They continue to require substantial support and opportunities to improve their social, economic, and health status. The Population Council hopes that this report will contribute significantly to the understanding of the lives of girls in Burkina Faso and inform future research and programs. New programs are necessary to achieve the Millennium Development Goals. A number of the actions outlined above will aid in the efforts to reach these goals and ensure the health of future generations. 
VI. APPENDIX: Activity register for youth-serving organizations

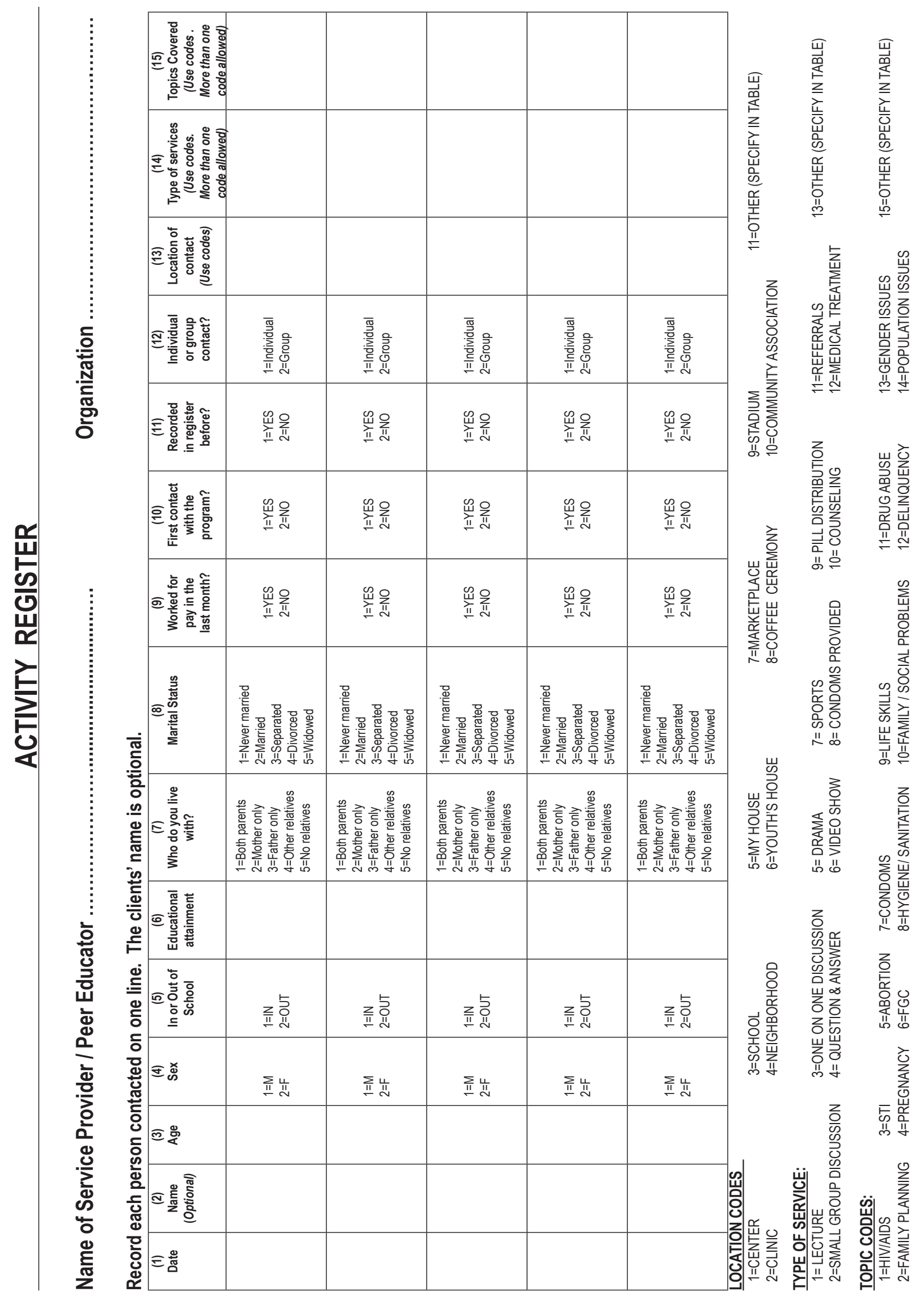




\section{Bibliography}

Abadian, Susan. 1996. "Women's autonomy and its impact on fertility." World Development 24(12): 1,793-1,809.

Alan Guttmacher Institute (AGI). 2004. "Adolescents in Burkina Faso: Sexual and reproductive health." Research in Brief, 2004 Series no. 3. New York: AGI.

Brady, Martha. 2002. "Safe Spaces for Adolescent Girls." Background Document Prepared by the Population Council for the UNFPA Workshop on Adolescent and Youth Sexual and Reproductive Health: Charting Directions for a Second Generation of Programming. New York: Population Council.

Brady, Martha, Ragui Assad, Barbara Ibrahim, A. Salem, R. Salem, and N. Zibani. 2006. Providing New Opportunities to Adolescent Girls in Socially Conservative Settings: The Ishraq Program in Rural Upper Egypt. New York: Population Council.

Bruce, Judith and Erica Chong. 2006. "The diverse universe of adolescents, and the girls and boys left behind: A note on research, program and policy priorities." Background paper to Public Choices, Private Decisions: Sexual and Reproductive Health and the Millennium Development Goals. New York: UN Millennium Project.

Bruce, Judith and Shelley Clark. 2003. "Including married adolescents in adolescent reproductive health and HIV/AIDS policy." Background paper for the WHO/UNFPA/Population Council Technical Consultation on Married Adolescents, Geneva: 9-12 December.

Burkina Faso, Ministère du Plan et de la Coopération, Conseil National de la Population. 1991. Politique de Population au Burkina Faso.

Burkina Faso, Ministère de la Santé, Comité National de Lutte contre le SIDA. 1994. Plan National Multisectoriel de Lutte contre les MST/SIDA.

Burkina Faso, Ministère de la Santé, Direction de la Santé de la Famille. 1998. Plan Stratégique de la Santé de Reproduction du Burkina Faso.

Burkina Faso, Ministère de l'Économie et des Finances, Conseil National de population. 2000. Programme d'Actions en Matière de Population 2001-2005.

Calvès, Anne-Emmanuèle. 2002. "Assessing adolescent reproductive health policies and programs: Case studies from Burkina Faso, Cameroon, and Togo." POLICY Working Paper Series No. 8. Washington, DC: USAID.

Calvès, Anne-Emmanuèle and Bruno Schoumaker. 2004. "Deteriorating economic context and changing patterns of youth employment in urban Burkina Faso: 1980-2000." World Development 32(8): 1,341-1,354.

Canadian International Development Agency. 2000. "Programming Profile for Burkina Faso, 2001-2011."

Center for Reproductive Rights (CRR). 1999. Women of the World: Laws and Policies Affecting Their Reproductive Lives, Francophone Africa. New York: CRR.
Central Intelligence Agency (CIA). The World Factbook. <http:// www.odci.gov/cia/publications/factbook/geos/uv.html>. Accessed 20 May 2004.

Ces Mille Jeunes Filles du Sourou. 2002. Film directed by Madeleine Sergooris and Raphael Dakissaga. 29 minutes. New York: Population Council.

Chege, Jane, lan Askew, and J. Liku. 2001. An Assessment of the Alternative Rites Approach for Encouraging Abandonment of Female Genital Mutilation in Kenya. New York: Population Council.

Chong, Erica, Kelly Hallman, and Martha Brady. 2006. "Investing when it counts: Generating the evidence base for policies and programs for very young adolescents-Guide and tool kit." New York: UNFPA and Population Council.

Clark, Shelley, Judith Bruce, and Annie Dude. 2006. "Protecting young women from HIV/AIDS: The case against child and adolescent marriage." International Family Planning Perspectives 32(2): 79-88.

Erulkar, Annabel. 2002. "Examining the gender dimensions of popular adolescent programming concepts: What do they offer adolescent girls and boys?" In Background Document Prepared by the Population Council for the UNFPA Workshop on Adolescent and Youth Sexual and Reproductive Health: Charting Directions for a Second Generation of Programming. New York: Population Council.

Gage-Brandon, Anastasia and Dominique Meekers. 1993. “The changing dynamics of family formation: Women's status and nuptiality in Togo." Paper presented at the International Union for the Scientific Study of Population Seminar on Women and Demographic Change in sub-Saharan Africa, Dakar, 3-6 March.

Guiella, Georges and Vanessa Woog. 2006. "Santé sexuelle et reproductive des adolescents au Burkina Faso: Résultats d'une enquête nationale en 2004." Occasional Report No. 21. New York: Alan Guttmacher Institute.

Hughes, Jane and Ann P. McCauley. 1998. "Improving the fit: Adolescents' needs and future programs for sexual and reproductive health in developing countries." Studies in Family Planning 29(2): 233-245.

Institut National de la Statistique et de la Démographie (INSD) et ORC Macro. 2004. Enquête Démographique et de Santé du Burkina Faso 2003. Calverton, MD: INSD et ORC Macro.

Lardoux, Solene. "Reaching the adolescents and youth: The cases of Burkina Faso, Guinea-Bissau and Mauritania." Forthcoming.

Lassina Sangaré, N.M., Salif Lankoandé, Eddy Van Dyck, Michel Cartoux, Issaka Pierre Compaoré, Joseph Catrayé, Paul Thomas Sanou, and Robert Soudré. 1997. "HIV infection among pregnant women in Burkina Faso: A nationwide serosurvey." International Journal of STD \& AIDS 8(10): 646-651.

Lloyd, Cynthia B. 2004. "Schooling and adolescent reproductive behavior in developing countries." Paper commissioned by Stan Bernstein for the UN Millennium Project. Unpublished. 
Lloyd, Cynthia B. and Barbara S. Mensch. 2006. "Marriage and childbirth among adolescents as factors in school dropout: An analysis of DHS data from sub-Saharan Africa." Paper presented at the Annual Meeting of the Population Association of America, Los Angeles, 30 March.

Mclntyre, Peter. 2002. Adolescent Friendly Health Services: An Agenda for Change. Geneva: WHO.

Mensch, Barbara and Cynthia B. Lloyd. 1998. "Gender differences in the schooling experiences of adolescents in low-income countries: The case of Kenya." Studies in Family Planning 29(2): 167-184.

Mensch, Barbara, Judith Bruce, and Margaret E. Greene. 1998. The Uncharted Passage: Girls' Adolescence in the Developing World. New York: Population Council.

Otoo-Oyortey, Naana and S. Pobi. 2003. “Early marriage and poverty: Exploring links for policy and programme development." London: Forum on Marriage and the Rights of Women and Girls in collaboration with the International Planned Parenthood Federation.

Pacific Institute for Women's Health (PIWH). 2002. Youth Sexuality: Action Research from Burkina Faso and Senegal. Los Angeles: PIWH.

Pathfinder International. 1999. Adolescent Reproductive Health in Africa: Paths into the Next Century. Nairobi: Pathfinder International Africa Regional Office.

Population Council. 1995. "Accelerating Girls' Education: A Priority for Governments." Fact sheet. New York: Population Council.

2002. Adolescent and Youth Sexual and Reproductive Health: Charting Directions for a Second Generation of Programming. Background Document for UNFPA/Population Council Workshop 1-3 May 2002. Unpublished.

_ 2005. "Building assets for safe, productive lives: A report on a workshop on adolescent girls' livelihoods." New York: Population Council.

Population Reference Bureau (PRB). 2005. 2005 World Population Data Sheet. Washington, DC: PRB.

2006. The World's Youth: 2006 Data Sheet. Washington, DC: PRB.

Rahman, Anika and Nahid Toubia. 2000. Female Genital Mutilation: A Practical Guide to Worldwide Laws and Policies. New York: Zed Books.

Saloucou, Lydia. 2002. Suivi des filles de la première promotion des centres de production et de formation pour jeunes filles du Sourou. Population Council unpublished report.
2002. Les filles de la deuxième promotion des centres de production et de formation pour jeunes filles du Sourou. Population Council, unpublished report.

2003. Etude diagnostique du vécu des filles et de leurs besoins en opportunités economiques et en santé de la reproduction. Population Council, unpublished report.

Saloucou, Lydia et al. 2002. "Diagnostic study on the life experience of married adolescent girls, their economic opportunities, and reproductive health needs: The case of Natiaboani and Koaré (Gourma Province)." New York: Population Council.

Save the Children. 2006. State of the World's Mothers 2006: Saving the Lives of Mothers and Newborns. Westport, CT: Save the Children.

Tipton, Margaret, Susan Igras, Rose Zambezi, and Marshall Ashley. 2003. "Multisectoral Programs Link Intervention Efforts." YouthLens on Reproductive Health and HIVIAIDS No. 7. Arlington, VA: YouthNet.

TOSTAN. 1999. Breakthrough in Senegal: Ending Female Genital Cutting. New York: Population Council.

UNAIDS (Joint United Nations Programme on HIV/AIDS). 2006. 2006 Report on the Global AIDS Epidemic. Geneva: UNAIDS.

United Nations Development Programme (UNDP). 2005. Human Development Report 2005. New York: UNDP.

United Nations Population Fund (UNFPA) and Population Reference Bureau (PRB). 2005. Country Profiles for Population and Reproductive Health: Policy Developments and Indicators. New York: UNFPA and PRB.

United States Department of State (USDOS). 2004. “Background Note: Burkina Faso." <www.state.gov/r/pa/ei/bgn/2834.htm>. Accessed 17 August 2004.

Weil, Olivier, Monique Munz, and Lydia Tapsoba. 2003. Addressing the Reproductive Health Needs and Rights of Young People Since ICPD: The Contribution of UNFPA and IPPF, Burkina Faso Country Evaluation Report. <http://www.unfpa. org/monitoring/country_evals/burkinafaso/burkinafaso_countryeval.pdf>. Accessed 17 August 2004.

World Bank. 2004. "Burkina Faso: Country Brief." <http://go. worldbank.org/U6XAAQ44R0>. Accessed 17 August 2004.

2005. "Burkina Faso at a Glance." <http://devdata. worldbank.org/AAG/bfa_aag.pdf>. Accessed 9 May 2006. 
(P) Population Council

www.popcouncil.org

36, Avenue de la Liberté

01 B.P. 6250

Ouagadougou, Burkina Faso

Tel: +22650 3112 42/3

Fax: +22650311246

One Dag Hammarskjold Plaza

New York, NY 10017 USA

Tel: +1 2123390500

Fax: +1 2127556052 